\title{
Novel and Efficient Chemoenzymatic Synthesis of D-Glucose- 6-Phosphate and Molecular Modeling Studies on the Selective Biocatalysis
}

\section{Tatiana Rodríguez-Pérez, ${ }^{[\mathrm{a}]}$ Iván Lavandera, ${ }^{[\mathrm{a}]}$ Susana Fernández, ${ }^{[\mathrm{a}]}$ Yogesh S. Sanghvi, ${ }^{[b]}$ Miguel Ferrero, ${ }^{[a]}$ and Vicente Gotor ${ }^{*[a]}$}

Keywords: Carbohydrates, Enzyme Catalysis, Molecular Modeling

\begin{abstract}
A concise chemoenzymatic synthesis of glucose-6-phosphate is described. Candida rugosa lipase was found to be an efficient catalyst for both regio- and stereoselective deacetylation of the primary hydroxyl group in the peracetylated D-glucose. In addition, we report an improved synthesis of 1,2,3,4,6-penta- $O$-acetyl- $\alpha$-D-glucopyranose providing a large-scale procedure for the acetylation of $\alpha$-D-glucose without isomerization at the anomeric center. The high overall yield and the easy scalability makes this chemoenzymatic strategy attractive for industrial application. Furthermore, molecular modeling of phosphonate transition-state analogue for the enzymatic hydrolysis step supports the substrate selectivity observed with Candida rugosa lipase.
\end{abstract}

\section{Introduction}

D-Glucose-6-phosphate (G-6-P) is vital to the glucide metabolism for higher organisms. It appears as an intermediate in several relevant routes such as glycolysis, gluconeogenesis, and in the synthesis and degradation of glycogen. Moreover, it has been widely used in pharmaceutical and medicinal chemistry applications. G-6-P is a normal constituent of the resting muscle and used in cases of low blood pressure, anesthesiology, asthenia, cardiology, and alcoholism. ${ }^{[1]}$ Interaction of

\footnotetext{
${ }^{[a]}$ Ms. T. Rodríguez-Pérez, Dr. I. Lavandera, Dr. S. Fernández, Prof. M. Ferrero, Prof. V. Gotor Departamento de Química Orgánica e Inorgánica and Instituto Universitario de Biotecnología de Asturias, Universidad de Oviedo, 33006-Oviedo (Asturias), Spain Fax: (+34)98 5103448

E-mails: MFerrero@fq.uniovi.es or VGS@fq.uniovi.es

${ }^{[b]}$ Dr. Y. S. Sanghvi

Rasayan Inc., 2802 Crystal Ridge Road, Encinitas, CA 92024-6615, USA

Fax: (+1) 7609441543

E-mail:Rasayan@sbcglobal.net
}

Supporting information for this article is available on the WWW under http://www.eurjoc.org or from the authors. 
aluminum (III), which accumulates in the organism is associated with some human pathologies, where G-6-P plays an important role in the intake and circulation of this ion in biological media. ${ }^{[2]}$ Conjugation of food proteins with G-6-P was useful in improving its functional properties such as water solubility, emulsifying activity, foaming and gel-forming properties. ${ }^{[3]}$ On the other hand, this metabolite is a key intermediate in the biosynthesis of clinically important 2-deoxy-streptaminecontaining aminocyclitol antibiotics ${ }^{[4]}$ and has proven to also be the metabolite involved in the stimulation of lipogenic enzyme gene expression. ${ }^{[5]}$

Robison and $\mathrm{King}^{[6]}$ were first to isolate G-6-P from a crude mixture of hexose monophosphates obtained by yeast fermentation. Phosphorylation of glucose in the presence of hexokinase and acetate kinase with ATP also furnished a route to G-6-P. ${ }^{[7]}$ The phosphorolysis of cellobiose to G-1-P which converts to G-6-P by phosphoglucomutase provides yet another procedure. ${ }^{[8]}$ Treatment of fructose 1,6-diphosphate with mild acid furnished fructose 6-phosphate which is transformed into G-6-P in the presence of glucose phosphate isomerase. ${ }^{[9]}$ Recently, bacterial acid phosphatases have been described as an alternative for production of G-6-P. ${ }^{[10]}$ The foregoing protocols are of limited value for scale-up because of the expensive enzymes used and the degradation of enzymes during the reaction and tedious isolation of the G-6-P from the reaction mixture.

Lardy and Fischer ${ }^{[11]}$ reported a 3-step protocol for the synthesis of G-6-P starting with 1,2,3,4-tetra- $O$-acetyl- $\beta$-D-glucopyranose (TAG). However, synthesis of the key starting material TAG is not straightforward and requires several protection-deprotection steps. ${ }^{[12]}$ Other chemical methods for the preparation of G-6-P describes the phosphorylation of glucose by phosphorus oxychloride, ${ }^{[13]}$ phosphorus pentoxide, or polyphosphoric acid. ${ }^{[14]}$ Unfortunately, direct phosphorylation of a polyhydroxy-sugar leads to unsatisfactory low yields and requires extensive purification. $^{[15]}$

The central role of G-6-P in biology and the increase in demand for industrial applications makes it a desirable target for synthesis. Most of the enzymatic approaches need very expensive and highly specific enzymes or cofactors, or proceed with low yields. Chemical routes involve extra protecting and deprotection steps to phosphitylate selectively the C-6-position. These limitations in the access to G-6-P motivated us to develop an efficient route for its synthesis on large-scale starting from TAG.

A major challenge faced by carbohydrate chemists is to orchestrate selective transformation of hydroxyl groups with similar reactivity in a single molecule. Enzyme-catalyzed reactions have been successfully utilized in selective deacylation or acylation of sugars and hence have provided an effective method of manipulating protecting-group strategies in carbohydrate synthesis. ${ }^{[16]}$ For example, Candida rugosa (CRL) and Pseudomonas fluorescens (PFL) lipases afford regioselective 
hydrolysis of acetylated glycopyranoses and glycopyranosides only in the C-6- and C-1-positions, respectively. ${ }^{[17]}$ These results obtained by Guisán and co-workers depend strictly on the use of enzyme preparations of PFL and CRL obtained by adsorption on an octyl agarose support. However, this reaction is limited to analytical scale because enzymes require purification and immobilization and these lipase forms are not commercially available. In another report, the esterase from Rhodosporidium toruloides has been used to catalyze the hydrolysis of a series of peracetylated $\alpha$-D-hexopyranoses and $\alpha$-D-hexopyranosides. For example, per-acetylated glucose has been selectively cleaved at the C-6-position, but the yield of the isolated 6-OH derivative was a modest $54 \% .^{[18]}$

Herein, we present a novel and efficient chemoenzymatic route to obtain G-6-P on a preparative scale, where the key step is the lipase-catalyzed regioselective hydrolysis of 1,2,3,4,6penta- $O$-acetyl- $\alpha$-D-glucopyranose (2) to furnish TAG. Different commercial lipases have been screened and various reaction parameters, such as temperature, co-solvent, and buffer $\mathrm{pH}$ are studied for yield optimization of TAG. We also propose the rationale for our finding of the enzyme selectivity during hydrolysis of 2 using computer-aided molecular modeling.

\section{Results and Discussion}

\section{Synthesis of 1,2,3,4,6-penta- $O$-acetyl- $\alpha$-D-glucopyranose (2)}

In order to develop a direct and concise synthesis of TAG, we needed good quality pentaacetate 2 as the starting material. Following a literature protocol, acylation of $\alpha$-D-glucose (1) with acetic anhydride in the presence of pyridine furnished 2 in $95 \%$ isolated yield (Scheme 1). The structure of 2 was confirmed by ${ }^{1} \mathrm{H}$ NMR, which shows a doublet for the $\alpha$-anomer at $6.39 \mathrm{ppm}$. However, the spectrum also showed a small doublet at $5.69 \mathrm{ppm}$ corresponding to the $\beta$-hydrogen on the anomeric carbon of 2.

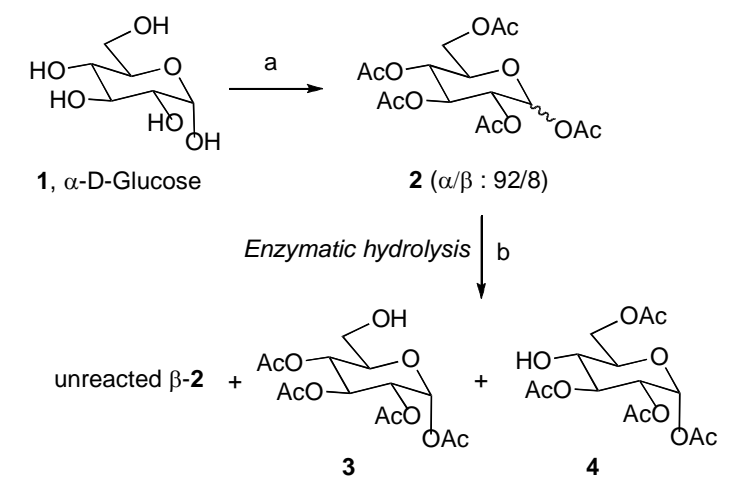

a) $\mathrm{Ac}_{2} \mathrm{O}, \mathrm{Py}, \mathrm{O}$ C-->r.t., $17 \mathrm{~h}(95 \%)$; b) see Table 1 and Table 2

\section{Scheme 1}

Integration of the ${ }^{1} \mathrm{H}$ NMR signals of compound 2 indicated that it is a mixture of $\alpha / \beta$ anomers in a ratio of 92:8. The observed ${ }^{1} \mathrm{H}$ NMR values are in accordance with the literature 
report. $^{[19]}$ A commercial sample of 2 also exhibited a similar ${ }^{1} \mathrm{H}$ NMR pattern for the $\alpha / \beta$ anomers. $^{[20]}$

\section{Enzymatic hydrolysis studies of 2}

The outcome of the synthesis led us to study the enzymatic hydrolysis of $\mathbf{2}$ as an anomeric mixture. Regioselective hydrolysis of $\mathbf{2}$ to $\mathbf{3}$ was carried out with commercial lipases only because of their easy access in bulk quantity and reliable activity. Six enzymes [Pseudomonas cepacia lipase (PSLC), Candida rugosa lipase (CRL), Candida antarctica lipase A (CAL-A), Candida antarctica lipase B (Novozym 435, CAL-B), Chirazyme L-2, and porcine pancreatic lipase (PPL)] were evaluated to determine which enzyme gives the best regioselectivity for transformation of $\mathbf{2}$ to $\mathbf{3}$. Interestingly, hydrolysis of the $\alpha / \beta$-mixture of 2 resulted in the non-reactive nature of the $\beta$-anomer and selective hydrolysis of the $\alpha$-anomer. Among the six enzymes tested, CRL afforded the best results where hydrolysis of the C-6 or C-4 acetyl group $(\sim 1: 1)$ of $\alpha-2$ occurred at $30{ }^{\circ} \mathrm{C}$ in $25 \mathrm{mM}$ phosphate buffer $\mathrm{pH} 4$ with acetonitrile as co-solvent $(20 \%) .{ }^{[17]}$ In our studies, the use of PSL-C triggered the hydrolysis at the C-1 and C-2 positions of 2 furnishing 3,4,6-tri- $O$-acetyl- $\alpha$-D-glucopyranose. Various attempts to hydrolyze 2 with CAL-A, CAL-B, PPL, and Chirazyme L-2 indicated that these enzymes were completely inert for an extended period of time (5-6 days) with full recovery of the unchanged starting materials $\alpha / \beta$-anomers (92:8).

\section{Process optimization of CRL mediated hydrolysis of 2}

The success with CRL prompted us to further investigate the influence of temperature and buffer $\mathrm{pH}$ on the rate and regioselectivity of enzymatic hydrolysis of $\mathbf{2}$. The increase in temperature from $30{ }^{\circ} \mathrm{C}$ to $60{ }^{\circ} \mathrm{C}$ has a dramatic effect on the conversion rate where enzyme activity was totally abolished at higher temperatures (entries $1 \square 4$, Table 1). We found that at $40{ }^{\circ} \mathrm{C}$ the $\mathrm{CRL}$ is able to maintain its activity and offer best selectivity toward the hydrolysis of the C-6 acetyl group in 2 . Modulation of the buffer $\mathrm{pH}$ clearly indicates that maximum activity is exhibited around $\mathrm{pH} 4-5$. The activity of CRL is compromised at a higher $\mathrm{pH}$ resulting in lower conversion rates (entries 5-7, Table 1).

Table 1. Hydrolysis catalyzed by CRL of 1,2,3,4,6-penta- $O$-acetyl- $\alpha$-D-glucopyranose (2). ${ }^{a, b}$

\begin{tabular}{|c|c|c|c|c|c|c|}
\hline Entry & $\mathrm{pH}$ & $20 \%$ co-solvent & $\mathrm{T}\left({ }^{\circ} \mathrm{C}\right.$ & $t(h)$ & conv. $(\%)^{c}$ & Ratio $\mathbf{3}: \mathbf{4}^{c}$ \\
\hline 1 & 4 & $\mathrm{CH}_{3} \mathrm{CN}$ & 30 & 2 & 43 & $48: 52$ \\
\hline 2 & 4 & $\mathrm{CH}_{3} \mathrm{CN}$ & 40 & 48 & 55 & $66: 34$ \\
\hline 3 & 4 & $\mathrm{CH}_{3} \mathrm{CN}$ & 50 & 48 & $<10$ & nd \\
\hline 4 & 4 & $\mathrm{CH}_{3} \mathrm{CN}$ & 60 & 48 & 0 & $\mathrm{sm}$ \\
\hline
\end{tabular}




$\begin{array}{lllllll}5 & 5 & \mathrm{CH}_{3} \mathrm{CN} & 40 & 48 & 58 & 64: 36 \\ 6 & 6 & \mathrm{CH}_{3} \mathrm{CN} & 40 & 48 & <10 & \text { nd } \\ 7 & 7 & \mathrm{CH}_{3} \mathrm{CN} & 40 & 48 & 0 & \mathrm{sm} \\ 8 & 4 & \mathrm{THF} & 40 & 95 & 0 & \mathrm{sm} \\ \mathbf{9} & \mathbf{4} & \mathbf{1 , 4 - d i o x a n e} & \mathbf{4 0} & \mathbf{2 7} & >\mathbf{9 7}^{d} & \mathbf{8 8 : 1 2} \\ 10 & 4 & \text { acetone } & 40 & 48 & 63 & 91: 9\end{array}$

${ }^{a}$ Starting material contains $8 \%$ of $1,2,3,4,6$-penta- $O$-acetyl- $\beta$-D-glucopyranose which was recovered unchanged. ${ }^{b}$ Enzymatic hydrolysis was carried out in $25 \mathrm{mM}$ phosphate buffer using $20 \%$ of co-solvent. ${ }^{c}$ Calculated by ${ }^{1} \mathrm{H}$ NMR integration. ${ }^{d}$ Conversion indicated as $>97 \%$ ( $\pm 3 \%$ by NMR analysis) means that no starting material was detected even at high spectrum amplitude. $\underline{\text { nd: }}$ not determined, $\underline{\text { sm: }}$ starting material recovered.

It is well established that the presence of a co-solvent during lipase-mediated hydrolysis could influence the outcome of selectivity in a favorable manner. To further increase the selectivity of the transformation of $\mathbf{2}$ to $\mathbf{3}$, we examined the use of THF, 1,4-dioxane and acetone as cosolvents. Improved results were obtained with 1,4-dioxane or acetone, whereas THF showed no hydrolysis (entries 8-10, Table 1). Use of 1,4-dioxane as a co-solvent offered excellent conversion (>97\%) of the two regioisomers 3 and $\mathbf{4}$ in a 88:12 ratio, respectively, in $27 \mathrm{~h}$. Although the use of acetone gave slightly better selectivity, the conversion was far too low to be in par with 1,4dioxane.

Table 2. Hydrolysis catalyzed by CRL of 1,2,3,4,6-penta- $O$-acetyl- $\alpha$-D-glucopyranose $(\mathbf{2})^{a}$ in 1,4-dioxane. ${ }^{b}$

\begin{tabular}{llllll} 
Entry & $\mathrm{pH}$ & $\mathrm{T}\left({ }^{\circ} \mathrm{C}\right)$ & $\mathrm{t}(\mathrm{h})$ & conv. $(\%)^{c}$ & Ratio 3:4 \\
\hline 1 & 4 & 40 & 27 & $>97^{d}$ & $88: 12$ \\
2 & 4 & 50 & 88 & 47 & $61: 39$ \\
$\mathbf{3}$ & $\mathbf{4}$ & $\mathbf{3 0}$ & $\mathbf{4 8}$ & $>\mathbf{9 7 ^ { d }}$ & $\mathbf{9 7 : 3}$ \\
4 & 4 & 25 & 72 & $>97^{d}$ & $92: 8$ \\
5 & 5 & 30 & 48 & $>97^{d}$ & $93: 7$ \\
6 & 6 & 30 & 48 & $>97^{d}$ & $90: 10$ \\
7 & 3 & 30 & 48 & 62 & $87: 13$
\end{tabular}

In anticipation of improving the product ratio, additional experiments were carried out in 1,4-dioxane as a co-solvent at variable temperature and $\mathrm{pH}$. The results are summarized in Table 2. Again, lower reaction temperature $\left(30^{\circ} \mathrm{C}\right)$ and lower buffer $\mathrm{pH} 4$ drove the hydrolysis catalyzed by CRL to completion furnishing isomers 3 and 4 in 97:3 ratio, respectively, in 48 h (entry 3, Table 2). Compounds 3 and $\mathbf{4}$ have identical $R_{f}$ values and their separation by chromatography was not 
practical. Gratifyingly, isolation of pure 3 via crystallization from a mixture of diethyl ether/ $n$ hexane (4:1) was possible leaving behind unreacted $\beta$-anomer of 2 and isomeric $\mathbf{4}$ in the mother liquor.

\section{An improved process for the synthesis of $\alpha$-anomeric 2 and its hydrolysis with CRL}

Our results indicate that $\mathrm{CRL}$ is highly regioselective in cleaving the $\mathrm{C}-6-\mathrm{O}$-acetyl group only from the $\alpha$-anomer in a mixture of $\alpha / \beta-2$. We were intrigued by the selective nature of $\mathrm{CRL}$ and questioned the possible use of pure $\alpha$-anomeric 2 to further improve the yield and isolation of the hydrolyzed 3. Our current route for the synthesis of $\mathbf{2}$ resulted in a mixture of two anomeric products (92:8). The use of commercial sample exhibited a similar pattern. This fact encouraged us to explore an improved synthesis of $\mathbf{2}$ where $\alpha$-anomer is the only product. A literature search for per- $O$-acetylation of carbohydrates ${ }^{[21]}$ revealed use of both exotic as well as simple reagents such as $\mathrm{Er}(\mathrm{OTf})_{3},{ }^{[22]} \mathrm{Ce}(\mathrm{OTf})_{3},{ }^{[23]} \mathrm{HClO}_{4}-\mathrm{SiO}_{2},{ }^{[24]}$ or iodine. ${ }^{[19,25]}$ However, cost, availability, toxicity, and difficulty in handling can limit the use of these catalysts on large-scale. In addition, epimerization at the anomeric carbon has been of serious concern. Because of these limitations, we decided to carefully investigate the current protocol with acetic anhydride in pyridine. We observed that lowering the reaction temperature improved the $\alpha$-anomeric ratio. Thus, using 8 equivalents of freshly distilled acetic anhydride and lowering the reaction temperature to $-10{ }^{\circ} \mathrm{C}, 1,2,3,4,6$-penta$O$-acetyl- $\alpha$-D-glucopyranose ( $\alpha$-2) was obtained as sole product in $96 \%$ yield (Scheme 2 ). Work-up and isolation of the product was easily done by simple precipitation from the reaction mixture without a need for further purification. With this simple improvement in place, we had pure $\alpha$ anomer of $\mathbf{2}$ in hand for further studies.

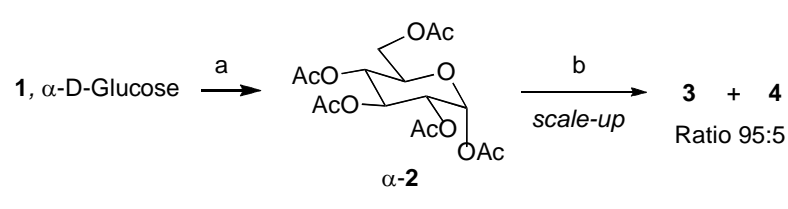

a) $\mathrm{Ac}_{2} \mathrm{O}, \mathrm{Py},-10 \square \mathrm{C}, 17 \mathrm{~h}(96 \%)$

b) CRL, $25 \mathrm{mMKH}_{2} \mathrm{PO}_{4}, \mathrm{pH} 4,1,4$-dioxane (20\%), 30 C, $48 \mathrm{~h}$ (95\%)

\section{Scheme 2}

Next, the enzymatic hydrolysis with CRL was set-up with $5 \mathrm{~g}$ of pure $\alpha$-D-peracetylated glucose ( $\alpha$-2) under fully optimized reaction conditions (Scheme 2). After $48 \mathrm{~h}$, we obtained a mixture of $\mathbf{3}$ and $\mathbf{4}$ (95:5 ratio, respectively) in 95\% yield. Clearly, this is an improvement over previous conditions where we had a mixture of three products (Scheme 1). However, we were puzzled with the formation of $\mathbf{4}$ in minor amounts despite the selectivity demonstrated by CRL. We argued that formation of $\mathbf{4}$ is due to the acyl group migration and not the CRL promiscuity. 


\section{Studies related to the confirmation of $O-4 \rightarrow O-6$ acyl migration in 3}

It is well documented that acyl groups have the propensity to migrate under both acidic or basic conditions. ${ }^{[17 \mathrm{~b}, 18]}$ Based on this fact, we decided to generate proof for the formation of $\mathbf{4}$ presumably via $O-4 \rightarrow O-6$ acyl migration in the compound 3. First, we carried out experiments in the absence of CRL to assure that the enzyme was not responsible for the acyl migration.

Table 3. Studies on transformation of $\mathbf{3}$ to $\mathbf{4}$ via acyl migration in the absence of enzyme. ${ }^{a}$

\begin{tabular}{lll} 
Entry & co-solvent & $\mathbf{3 : 4}$ final ratio $^{b}$ \\
\hline 1 & 1,4-dioxane & $86: 14$ \\
2 & THF & $86: 14$ \\
3 & $\mathrm{CH}_{3} \mathrm{CN}$ & $82: 18$ \\
4 & acetone & $80: 20$
\end{tabular}

${ }^{a}$ Reaction conditions: initial ratio 3:4 is $91: 9,25 \mathrm{mM}$ phosphate buffer using $20 \%$ of co-solvent and at $30{ }^{\circ} \mathrm{C}$ during $48 \mathrm{~h} .{ }^{b} \mathrm{Calculated}$ by ${ }^{1} \mathrm{H}$ NMR.

As expected, the results in Table 3 indicated that the acyl group undergoes migration from $O-4$ to $O-6$ in all co-solvents tested. The rearrangement was slower in 1,4-dioxane and THF compared to the acetonitrile and acetone (entries 1-4, Table 3). These experiments were carried out with $25 \mathrm{mM}$ phosphate buffer in the presence of the co-solvent. Next, we wanted to better understand the role of phosphate buffer in the CRL mediate hydrolysis process. Therefore, we designed another set of experiments only with organic solvents.

The evaluation of acyl group migration was performed in four organic solvents that were used for the prior studies. No evidence of the $O-4 \rightarrow O-6$ acyl migration was found in 1,4-dioxane or THF (entries 1 and 2, Table 4) determined by ${ }^{1} \mathrm{H}$ NMR data. Interestingly, the acyl migration was observed in acetonitrile or acetone as a solvent (entries 3 and 4, Table 4). These experiments suggest that acyl migration could take place either in organic solvents alone or mixed with the phosphate buffer.

Table 4. Studies on transformation of $\mathbf{3}$ to $\mathbf{4}$ via acyl migration in the organic solvents ${ }^{a}$

\begin{tabular}{lll} 
Entry & co-solvent & $\mathbf{3 : 4}$ final ratio $^{b}$ \\
\hline 1 & 1,4-dioxane & $91: 9$ \\
2 & THF & $91: 9$ \\
3 & $\mathrm{CH}_{3} \mathrm{CN}$ & $71: 29$ \\
4 & acetone & $87: 13$
\end{tabular}

${ }^{a}$ Reaction conditions: initial ratio 3:4 is $91: 9,30{ }^{\circ} \mathrm{C}$ during 48 h. ${ }^{b}$ Calculated by ${ }^{1} \mathrm{H}$ NMR. 


\section{Studies related to the confirmation of the selectivity demonstrated by CRL}

Next, we wished to generate clear chemical evidence that the CRL is not responsible for the formation of 4. For this, we synthesized 1,2,3,4-tetra- $O$-acetyl-6- $O$-benzoyl- $\alpha$-D-glucopyranose (5) from 1,2,3,4-tetra- $O$-acetyl- $\alpha$-D-glucopyranose (3) via benzoylation with benzoyl chloride in pyridine (Scheme 3). Installation of a 6-O-benzoyl group in 5 allowed us to test the selectivity of CRL under a modified chemical environment. Treatment of 5 with CRL under hydrolytic conditions provided a mixture of $6-\mathrm{OH}$ and $4-\mathrm{OH}$ derivatives 3 and $\mathbf{4}$ in a 97:3 ratio, respectively. This experiment further confirmed that CRL is able to recognize the 6-position in $\mathbf{5}$ to afford $\mathbf{3}$, despite of a bulky acyl group. Should CRL be promiscuous in its activity we would have seen the formation of 1,2,3-tri- $O$-acetyl-6- $O$-benzoyl- $\alpha$-D-glucopyranose (6). The later compound was not detected in the reaction mixture.

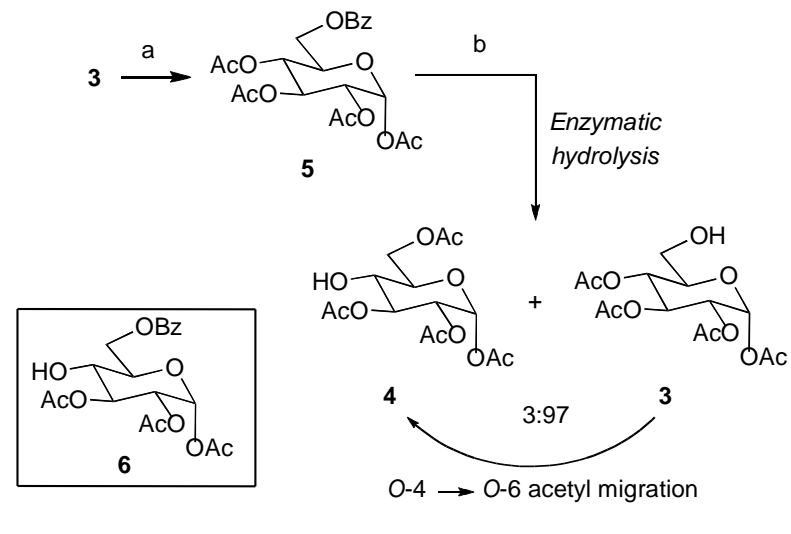

a) $\mathrm{BzCl}, \mathrm{Py}, 0 \subset \mathrm{C}-->$ r.t., overnight $(88 \%)$

b) CRL, $25 \mathrm{mM} \mathrm{KH}_{2} \mathrm{PO}_{4}, \mathrm{pH} 4$, 1,4-dioxane (20\%), $30 \sqsubset \mathrm{C}, 49 \mathrm{~h}(91 \%)$

\section{Scheme 3}

Further evidence for the selectivity of CRL was demonstrated by enzyme-catalyzed hydrolysis of the ${ }^{13} \mathrm{C}$ labeled (C-6 position in $\alpha-2^{*}$, Scheme 4$)$ peracetylated $\alpha$-D-glucose. The $\alpha-$ $2^{*}$ was conveniently synthesized by acylation of $\mathbf{3}$ with ${ }^{13} \mathrm{C}$ labeled acetic anhydride in pyridine at room temperature. The CRL mediated hydrolysis of $\alpha-2^{*}$ furnished a mixture of unlabeled compounds 3 and 4 in 96:4 ratio, respectively. Assuming that the CRL was responsible for the hydrolysis at the $\mathrm{C}-4$ position, the product in the foregoing reaction should have been the ${ }^{13} \mathrm{C}$ labeled derivative $4^{*}$ (Scheme 4 ). The ${ }^{13} \mathrm{C}$ NMR experiment of the reaction mixture confirmed that the label was totally absent in the products. Therefore, we propose that the CRL selectively transforms 2 or 5 into 3, which undergoes $O-4 \rightarrow O-6$ acetyl migration furnishing the regioisomer 4 as a minor by-product. 


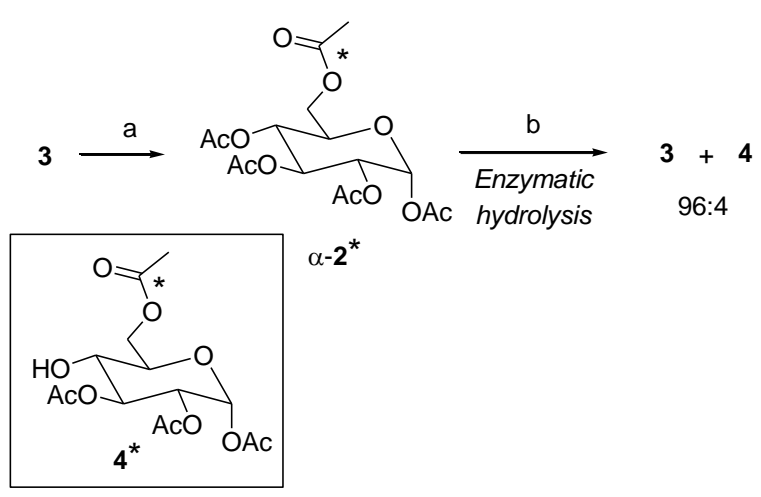

a) $\left(\mathrm{Me}^{13} \mathrm{CO}\right)_{2} \mathrm{O}$, Py, r.t., $16 \mathrm{~h}(99 \%)$; b) $\mathbf{C R L}, 25 \mathrm{mM} \mathrm{KH}_{2} \mathrm{PO}_{4}$ $\mathrm{pH} 4,1,4$-dioxane $(20 \%), 30^{\circ} \mathrm{C}, 48 \mathrm{~h}(91 \%)$

\section{Scheme 4}

In order to decrease the possibility of acetyl migration, we increased the amount of CRL during hydrolysis reaction. Indeed, the overall reaction time was reduced from 48 to $24 \mathrm{~h}$ but the ratio of hydrolyzed products $\mathbf{3}$ and $\mathbf{4}$ remain unchanged. This experiment provided additional support to our hypothesis that CRL did not trigger the acyl migration during hydrolysis step.

Recently, Otera and co-workers ${ }^{[26]}$ described a chemical deprotection strategy using $\left[{ }^{t} \mathrm{Bu}_{2} \mathrm{SnOH}(\mathrm{Cl})\right]_{2}$ for the synthesis of $\mathbf{3}$ from 2. Despite of good yield (88\%), this protocol has severe limitations due to the toxicity of tin and the lack of a commercial source for the organotin catalyst. In comparison, our enzymatic protocol allows the synthesis of $\mathbf{3}$ in high yield through a much simpler procedure using a commercial catalyst that is biodegradable and has many environmental advantages over other traditional chemical processes.

\section{Phosphorylation studies of 3 leading to synthesis of G-6-P}

With a convenient synthesis of $\mathbf{3}$ in hand, the stage was set for phosphorylation at the 6-OH group. We decided to use a mixture of $\mathbf{3}$ and $\mathbf{4}$ (97:3 ratio) assuming that phosphorylation of the C4 secondary hydroxyl group of the minor impurity will be significantly slower and may not compete with the reaction of the primary hydroxyl group in $\mathbf{3}$. Thus, treatment of the sugars $\mathbf{3}$ and $\mathbf{4}$ with diphenylchlorophosphate in pyridine and DMAP gave the phosphate $\mathbf{7}$ in a moderate yield of 58\% (Scheme 5). The reaction was further optimized by performing phosphorylation in methylene chloride as a solvent and $\mathrm{Et}_{3} \mathrm{~N}$ as a base instead of pyridine. Phosphate 7 was formed in $85 \%$ isolated yield under these conditions. A trace amount of the undesired phosphate $\mathbf{8}$ was also observed. This byproduct was separated easily from 7 by filtration on silica gel followed by precipitation in $\mathrm{CHCl}_{3} / n$-hexane.

Reductive cleavage of the phenyl groups in the phosphate was carried out by hydrogenolysis with platinum (IV) oxide to give deprotected phosphate 9 in quantitative yield. The acetyl groups 
were removed by saponification with $\mathrm{K}_{2} \mathrm{CO}_{3}$ in $\mathrm{MeOH}$, and subsequent treatment with Dowex 50W afforded the desired G-6-P $\mathbf{1 0}$ in $99 \%$ yield.

We repeated the synthesis of G-6-P on 10 grams scale following our five-step protocol starting from $\alpha$-D-glucose in $77 \%$ overall yield. We find this protocol to be very efficient because it utilized only one chromatographic step. The ${ }^{1} \mathrm{H}$ NMR spectrum of the G-6-P synthesized herein showed the distinctive anomeric signal of the $\alpha$-and $\beta$-anomers at 5.10 and 4.53 ppm, respectively, in a 60:40 ratio. This data is in accordance with the literature report and correlated with the reference sample purchased from a commercial supplier.

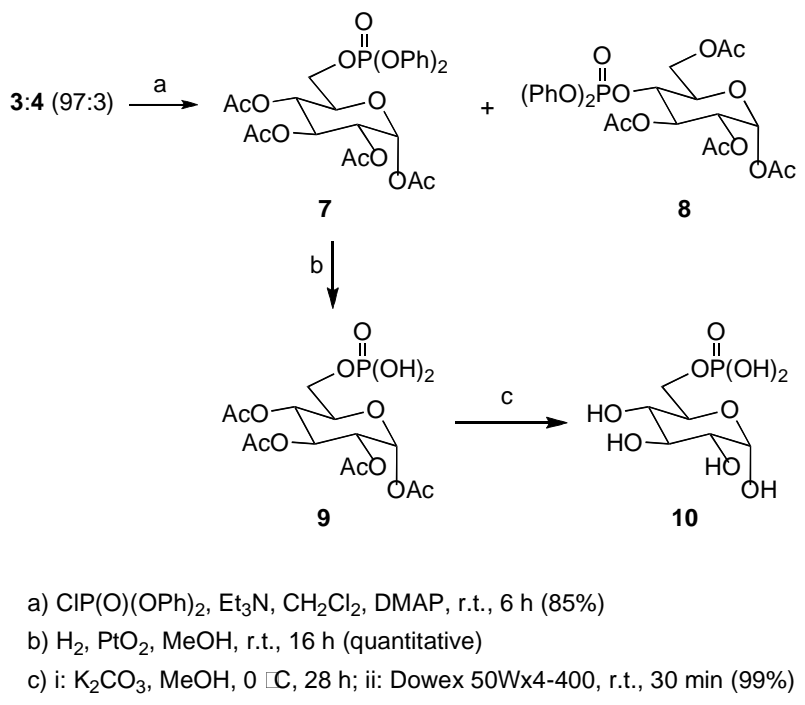

\section{Scheme 5}

Although the chemical purity of the G-6-P was confirmed by NMR and optical rotation, it was important to assure that this product possesses its biochemical activity measured by an enzymatic assay. ${ }^{[28]}$ Therefore, our sample of G-6-P was converted by glucose 6-phosphate dehydrogenase (EC 1.1.1.49) to 6-phosphogluconolactone following a literature protocol. ${ }^{[29]}$ In this experiment, we also compared the activity of our product with three commercial G-6-P samples purchased from Sigma, Fluka and Roche (Figure 1). This data provided convincing evidence that the G-6-P prepared by our protocol is biologically active. 


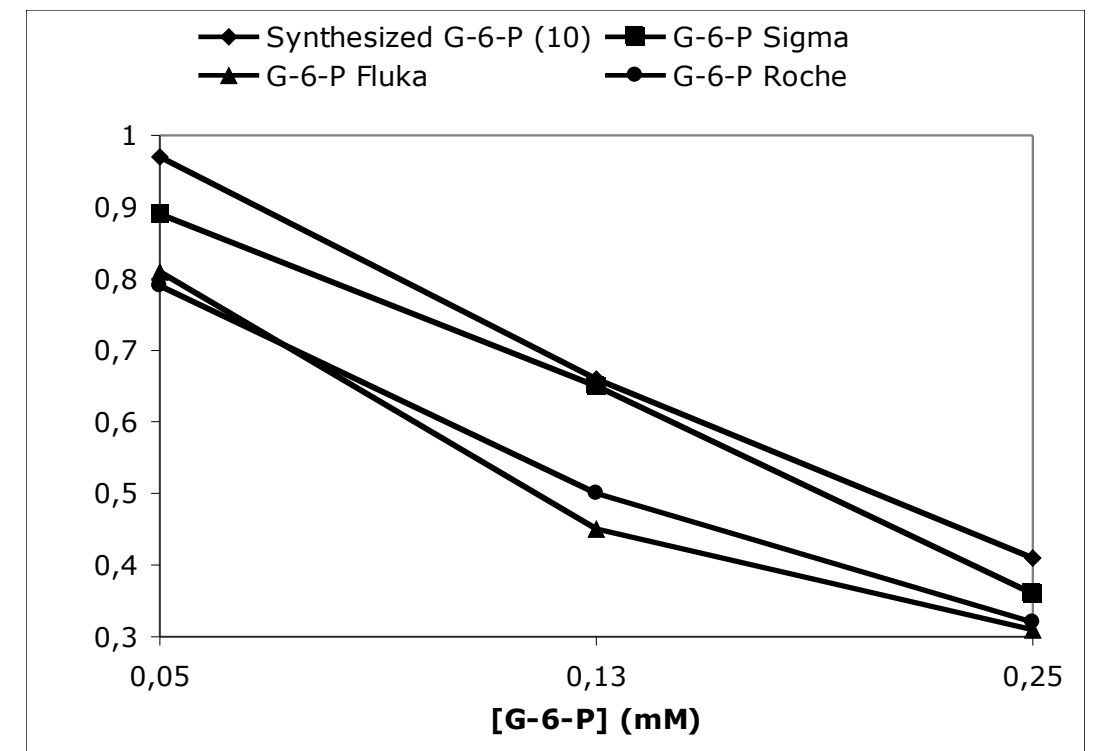

Figure 1. Activity of different commercial G-6-P sources compared with G-6-P synthesized in this study (10).

\section{Molecular modeling studies}

The exceptionally high regio- and stereoselectivity observed with the CRL-catalyzed hydrolysis of the anomeric mixture of peracetylated D-glucose motivated us to undertake a modeling study of this reaction to better understand the results. Thus, we obtained the X-ray structure of the open form of CRL (1LPM) ${ }^{[30]}$ from the Protein Data Bank. This structure presents an inhibitor covalently linked to the active site. The catalytic triad is formed by residues Glu341-His449-Ser209 and the oxyanion hole is formed by the main chain $\mathrm{NH}$ groups of residues Gly123, Gly124, and Ala210. ${ }^{[30,31]}$

To qualitatively explain the regioselectivity of CRL, we modeled phosphonate analogues of the key intermediates for hydrolysis of both anomers of peracetylated glucose 2 . Both phosphonates were able to mimic key features of the intermediates in hydrolysis reactions and allowed the computationally simpler molecular mechanics approach to be used. This approach focuses on how the substrate fits in the enzyme, but might omit subtle details about the transition state. We started with a simplified phosphonate that mimicked the tetrahedral intermediate for the hydrolysis of ethyl acetate (Figure 2). Geometry optimization yielded a structure containing all six catalytically essential hydrogen bonds in the catalytic site. To model the sugar substrates, we replaced the ethoxy moiety with the $\alpha$ - or $\beta$-D-glucose group linked to the phosphonate at 6-position and then added the other four acetate groups. We carried out a systematic search in order to identify the catalytically productive conformations (see Experimental Section), which we defined as those that: a) contained all six catalytically essential hydrogen bonds (a-e, in addition of key hydrogen bond between $\mathrm{N}_{\delta}$ of His449 and the carboxylate of Glu341) shown in Figure 2; b) avoided steric hindrances between the 
peracetylated glucose phosphonate and the lipase, and c) avoided internal steric clashes within the phosphonate. After several arrangements of the $\alpha$-anomer sugar within the active site of the lipase, a model (Figure 3A) in which this substrate perfectly fitted was derived. This model was devoid of any steric hindrances and maintained all the six key hydrogen-bond interactions (Figure $3 \mathrm{~B}$ ). ${ }^{[32]}$ The sugar was partly shared between the acyl pocket and the alcohol pocket of the lipase, thus an additional $\mathrm{H}$-bond was observed between the anomeric carbonyl oxygen and the $\mathrm{OH}$ of residue Ser450 (Figure 3B, bond f, $2.84 \AA$ ). ${ }^{[33]}$ These interactions can fix the sugar substrate in a desirable manner to react regioselectively towards the $O-6$ position.

When the $\beta$-anomer was built and minimized, no single productive conformation was obtained. In all structures some of the key H-bond interactions were lost. Finally, we tried to place the $\beta$-anomer structure in a similar way as that for the $\alpha$-anomer (Figure $3 \mathrm{C}$ ); the substrate moved away from the catalytic His449 ( $b=3.63 \AA$, Figure $3 \mathrm{D})$ site and two of the oxyanion key hydrogen bonds [c=2.88 $\AA$, angle $(\mathrm{N}-\mathrm{H}-\mathrm{O})=117^{\circ}$; e= $3.59 \AA$, Figure $3 \mathrm{D}$ ] were lost. ${ }^{[32]}$

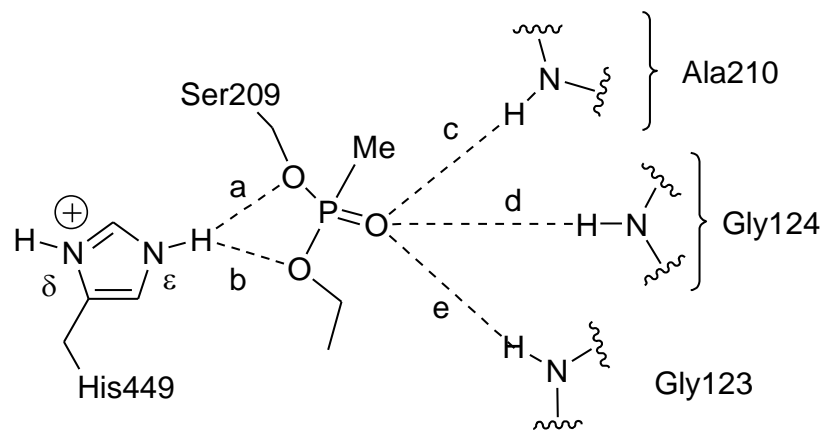

Figure 2. Tetrahedral intermediate phosphonate transition-state analogue used to mimic the hydrolysis of ethyl acetate in computer modeling. Key hydrogen bonds between CRL and the tetrahedral intermediate analogue are: two from $\mathrm{N}_{\varepsilon}$ of His449 to the oxygen atom of Ser209 (a) and the OEt group of the tetrahedral intermediate (b), and three from the oxyanion to Ala210 (c), to Gly124 (d), and to Gly123 (e). A sixth key hydrogen bond is from $\mathrm{N}_{\delta}$ of His449 to the carboxylate of Glu341 (not shown). Further, the OEt group is replaced by $\alpha$ - or $\beta$-glucose peracetylated in a stepwise fashion as described in the text. 

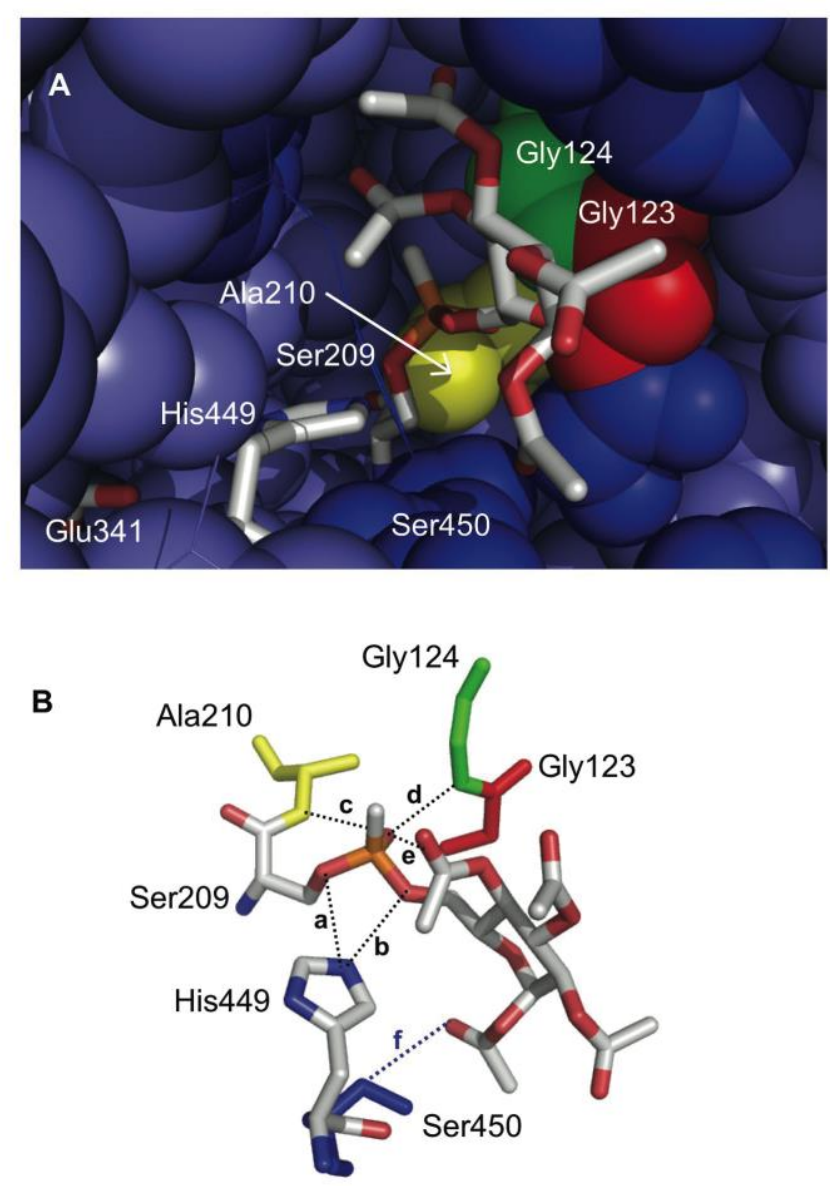
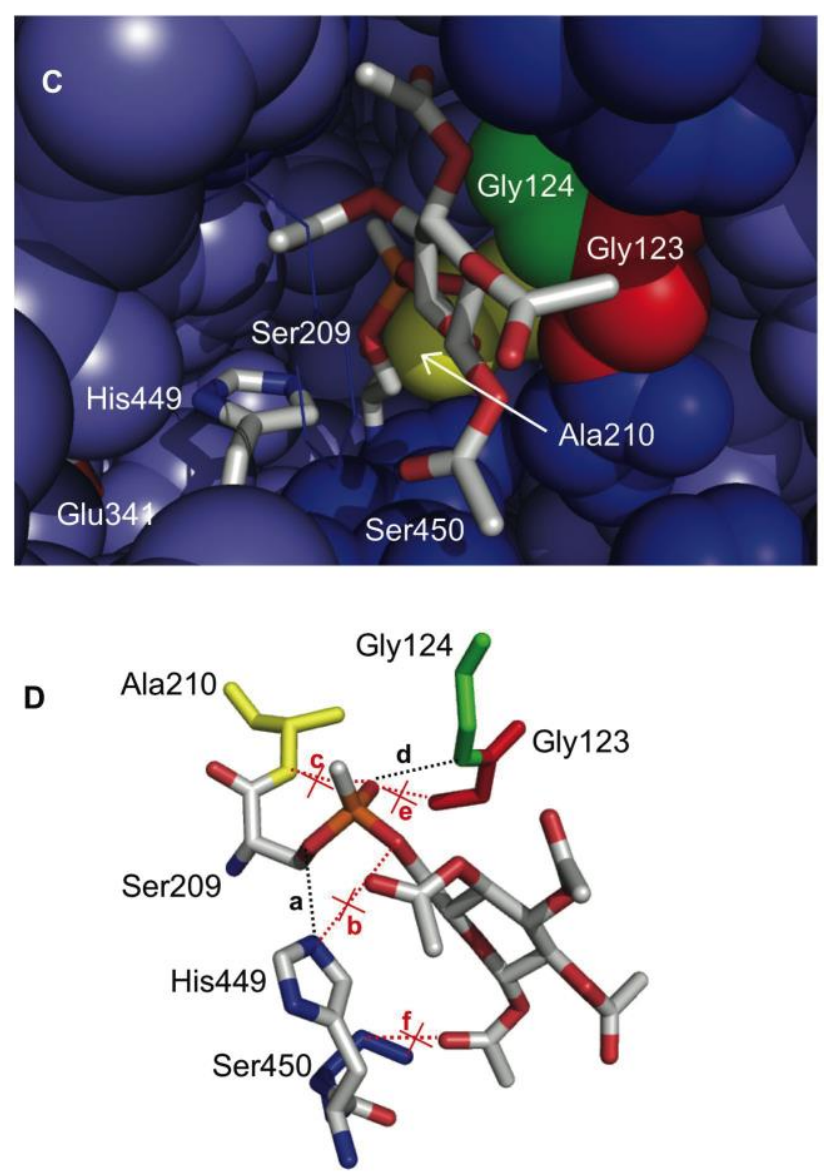

Figure 3. Best models of phosphonate analogues for CRL-catalyzed hydrolysis of peracetylated glucose. Residues surrounding the active site (Glu208, Gly122, Phe133, Phe296, Ile297, Phe344, Phe345, Ser450, and Ile453) are colored dark blue. The oxyanion hole residues Gly123, Gly124, and Ala210 are colored red, green, and yellow, respectively. A) Peracetylated $\alpha$-glucose conformation of the phosphonate mimics hydrolysis of the 6-acetate group, it places the anomeric acetate carbonyl group close to Ser450 forming an additional hydrogen bond (bond $\mathrm{f}$, in a detailed view in panel B), in addition of the key hydrogen bonds (a-e in panel B, a sixth key hydrogen bond between Glu341 and His449 is not shown). C) Peracetylated $\beta$-glucose conformation of the phosphonate does not form the same additional hydrogen bond $\mathrm{f}$ because of the bad angle $\left[\mathrm{f}=2.82 \AA\right.$, angle $\left.(\mathrm{O}-\mathrm{H}-\mathrm{O})=84^{\circ}\right]$, and also loses three key hydrogen bonds (bonds b, c, and e; panel D; see text). To allow a better view of the active site, panel A (Phe344 and Leu445) and panel C (Phe344) display some amino acids in a line representation.

\section{Conclusions}

In conclusion, the route detailed here has proven to be a highly efficient method for the large-scale synthesis of D-glucose-6-phosphate. A versatile acetylating method, very useful in carbohydrate chemistry has been developed based on lower reaction temperature $\left(-10{ }^{\circ} \mathrm{C}\right)$ and use of freshly distilled acetic anhydride. Under these conditions, exclusively 1,2,3,4,6-penta- $O$-acetyl- $\alpha$-Dglucopyranose was obtained. In addition, the enzymatic hydrolysis of peracetylated $\alpha$-D-glucose catalyzed by the commercial Candida rugosa lipase allowed the regioselective deprotection of the 
C-6-acetyl group in excellent yield. An acetyl migration from $O-4$ to $O-6$ explains the formation of the 4-OH deprotected derivative as a minor byproduct. It is worth emphasizing that the preparation of G-6-P is accomplished in 77\% overall yield from readily available starting material and requires only one chromatographic step. This work provides further evidence that the combined use of enzymatic and conventional chemical methods offers a convenient alternative to the synthesis of biological active molecule with a host of pharmaceutical applications.

Results obtained from the molecular modelling study on the enzymatic step are in agreement with the observed experimental data. Thus, review of our results indicated that the location of the acetyl group in the anomeric position has a strong influence in the reactivity of the enzyme. More importantly, the existence of this interaction between the $O$-1-carbonyl group and Ser450 could explain the data obtained when another type of moiety is present in the anomeric position. In this sense, it has been described by Terreni et al. ${ }^{[17 b]}$ that when the acetyl group in the $\beta$-anomer is changed by a methoxy ether (smaller group) or a butoxy ether (bigger moiety), the CRL-catalyzed hydrolysis in the 6-position is accomplished, pointing out again the relevance of the nature of the group present at the anomeric carbon.

This study constitutes another fine example of how remote interactions can affect the stereoand/or regioselectivity of an enzyme. ${ }^{[34]}$ The key difference between the intermediates obtained for both peracetylated anomers of D-glucose is the superior binding of the $\alpha$-intermediate caused at a site remote from the reaction center. Such remote binding can lower the free energy of the corresponding transition state by favoring a catalytically productive orientation, and at the same time disfavoring the intermediate for the observed $\beta$-anomer.

\section{Experimental Section}

\section{General}

Candida rugosa lipase (CRL, Type VII, $1410 \mathrm{U} / \mathrm{mg}$ ) was purchased from Sigma. $[\alpha]_{\mathrm{D}}$ values are given in $10^{-1} \mathrm{deg} \mathrm{cm}^{2} \mathrm{~g}^{-1}$.

\section{Molecular Modeling}

The program Insight II, version 2000.1, was used for viewing the structures. The geometric optimizations and molecular dynamics were performed using Discover, version 2.9.7 (Accelrys, San Diego CA, USA), using the AMBER ${ }^{[35]}$ force field. The distance dependent dielectric constant was set to 4.0 to mimic the electrostatic shielding of the solvent and the 1-4 van der Waals interactions were scaled to $50 \%$. The crystal structure for the CRL $\left(1 \mathrm{LPM}^{[30]}\right)$ was obtained from the Protein Data Bank (www.pdb.org), and includes a phosphonate. The methodology followed for localization of energy minima structures by means of a systematically search has been described elsewhere (also 
see Electronic Supplementary Information). ${ }^{[36]}$ Protein structures in Figure 3 were generated using PyMOL 0.99. ${ }^{[37]}$

\section{1,2,3,4,6-Penta- $O$-acetyl-D-glucopyranose (2).}

Acetic anhydride $(12 \mathrm{~mL}, 0.13 \mathrm{~mol})$ was added drop wise to a stirred solution of $\alpha$-D-glucose (3.0 $\mathrm{g}, 17 \mathrm{mmol})$ in anhydrous pyridine $(30 \mathrm{~mL})$ at $0{ }^{\circ} \mathrm{C}$. After stirring at room temperature for $17 \mathrm{~h}$, the solvent was evaporated under vacuum, and the residue was purified by flash chromatography (EtOAc/ $n$-hexane 1:2) to afford $6.2 \mathrm{~g}$ of 2 (ratio $\alpha / \beta: 92 / 8$ ) as a white solid (95\% yield). ${ }^{1} \mathrm{H}$ NMR $\left(\mathrm{CDCl}_{3}, 300 \mathrm{MHz}\right.$ ): $\delta$ 2.01-2.18 (several s, $30 \mathrm{H}, 10 \mathrm{CH}_{3} \alpha$ anomer and $\beta$ anomer), 3.81-3.86 (m, $1 \mathrm{H}$, H-5 $\beta$ anomer), 4.05-4.15 (m, 3H, H-5+H-6 $\alpha$ anomer, H-6 $\beta$ anomer), 4.25 (dd, 2H, H-6 $\alpha$ anomer, ${ }^{2} J_{\mathrm{HH}} 12.4,{ }^{3} J_{\mathrm{HH}} 4.1 \mathrm{~Hz}$, and H-6 $\beta$ anomer), $5.10\left(\mathrm{dd}, 2 \mathrm{H}, \mathrm{H}-2 \alpha\right.$ anomer, ${ }^{3} J_{\mathrm{HH}} 10.2,{ }^{3} J_{\mathrm{HH}} 3.5 \mathrm{~Hz}$, and $\mathrm{H}-2 \beta$ anomer), 5.14 (t, 2H, H-4 $\alpha$ anomer, ${ }^{3} J_{\mathrm{HH}} 9.8 \mathrm{~Hz}$, and $\mathrm{H}-4 \beta$ anomer), 5.24 (t, 1H, H-3 $\beta$ anomer, $\left.{ }^{3} J_{\mathrm{HH}} 9.2 \mathrm{~Hz}\right), 5.47\left(\mathrm{t}, 1 \mathrm{H}, \mathrm{H}-3 \alpha\right.$ anomer, $\left.{ }^{3} J_{\mathrm{HH}} 9.9 \mathrm{~Hz}\right), 5.69\left(\mathrm{~d}, 1 \mathrm{H}, \mathrm{H}-1 \beta\right.$ anomer, ${ }^{3} J_{\mathrm{HH}} 8.1$ $\mathrm{Hz}), 6.39$ (d, $1 \mathrm{H}, \mathrm{H}-1 \alpha$ anomer, $\left.{ }^{3} J_{\mathrm{HH}} 3.8 \mathrm{~Hz}\right)$.

\section{$1,2,3,4,6$-Penta- $O$-acetyl- $\alpha$-D-glucopyranose $(\alpha-2) .{ }^{[17 a]}$}

Freshly distilled acetic anhydride $(12 \mathrm{~mL}, 0.13 \mathrm{~mol})$ was added drop wise to a stirred solution of $\alpha$ D-glucose $(3.0 \mathrm{~g}, 17 \mathrm{mmol})$ in anhydrous pyridine $(15 \mathrm{~mL})$ at $-10{ }^{\circ} \mathrm{C}$, and the stirring continued at the same temperature for $17 \mathrm{~h}$. After addition of ice into the reaction mixture a powdery white solid precipitated. Filtration of the solid affords $6.3 \mathrm{~g}$ of $\alpha-2$ (96\% yield). $\underline{R}_{f}$ (EtOAc): 0.64; mp 110-112 ${ }^{\circ} \mathrm{C} ;[\alpha]_{\mathrm{D}}{ }^{20}+101$ (c 1.0 in $\left.\mathrm{CHCl}_{3}\right) ; \mathrm{IR}(\mathrm{KBr}): v$ 2940, 2875 and $1753 \mathrm{~cm}^{-1} ; \underline{{ }^{1} \mathrm{H} \mathrm{NMR}}\left(\mathrm{CDCl}_{3}, 300\right.$ $\mathrm{MHz}): \delta 2.03\left(\mathrm{~s}, 3 \mathrm{H}, \mathrm{CH}_{3}\right), 2.05\left(\mathrm{~s}, 3 \mathrm{H}, \mathrm{CH}_{3}\right), 2.07\left(\mathrm{~s}, 3 \mathrm{H}, \mathrm{CH}_{3}\right), 2.10\left(\mathrm{~s}, 3 \mathrm{H}, \mathrm{CH}_{3}\right), 2.19(\mathrm{~s}, 3 \mathrm{H}$, $\left.\mathrm{CH}_{3}\right), 4.08-4.15$ (m, 2H, H-5+H-6), 4.28 (dd, 1H, H-6, $\left.{ }^{2} J_{\mathrm{HH}} 12.6,{ }^{3} J_{\mathrm{HH}} 4.2 \mathrm{~Hz}\right), 5.11$ (dd, 1H, H-2, $\left.{ }^{3} J_{\mathrm{HH}} 10.1,{ }^{3} J_{\mathrm{HH}} 3.7 \mathrm{~Hz}\right), 5.14\left(\mathrm{t}, 1 \mathrm{H}, \mathrm{H}-4,{ }^{3} J_{\mathrm{HH}} 9.6 \mathrm{~Hz}\right.$ ), $5.48\left(\mathrm{t}, 1 \mathrm{H}, \mathrm{H}-3,{ }^{3} J_{\mathrm{HH}} 9.6 \mathrm{~Hz}\right), 6.33(\mathrm{~d}, 1 \mathrm{H}$, $\left.\mathrm{H}-1,{ }^{3} J_{\mathrm{HH}} 3.7 \mathrm{~Hz}\right) ;{ }^{13} \mathrm{C} \mathrm{NMR}\left(\mathrm{CDCl}_{3}, 75.5 \mathrm{MHz}\right): \delta 20.3\left(\mathrm{CH}_{3}\right), 20.4\left(\mathrm{CH}_{3}\right), 20.5\left(\mathrm{CH}_{3}\right), 20.6\left(\mathrm{CH}_{3}\right)$, $20.7\left(\mathrm{CH}_{3}\right), 61.3\left(\mathrm{CH}_{2}\right), 67.8(\mathrm{C}-4), 69.1(\mathrm{C}-2), 69.7(\mathrm{C}-3+\mathrm{C}-5), 88.9(\mathrm{C}-1), 168.6(\mathrm{C}=\mathrm{O}), 169.3$ $\left.(\mathrm{C}=\mathrm{O}), 169.5(\mathrm{C}=\mathrm{O}), 170.1(\mathrm{C}=\mathrm{O}), 170.5(\mathrm{C}=\mathrm{O}) ; \mathrm{MS}_{(\mathrm{ESI}}^{+}, \mathrm{m} / \mathrm{z}\right): 413\left[(\mathrm{M}+\mathrm{Na})^{+}, 100 \%\right]$.

\section{Enzymatic hydrolysis of $\alpha-2$.}

A mixture of $\boldsymbol{\alpha}-\mathbf{2}(5.0 \mathrm{~g}, 12.81 \mathrm{mmol})$, Candida rugosa lipase (2.5 g), and $25 \mathrm{mM}$ phosphate buffer pH 4 which contain $20 \%$ of 1,4-dioxane $(600 \mathrm{~mL})$ was stirred $(250 \mathrm{rpm})$ at $30^{\circ} \mathrm{C}$ during $48 \mathrm{~h}$. The progress of the reaction was monitored by TLC (EtOAc). The suspension was filtered on celite, the enzyme washed with 1,4-dioxane and EtOAc, and the residue extracted with EtOAc. Solvents were evaporated under vacuum, and the residue analyzed by ${ }^{1} \mathrm{H}$ NMR, which indicated a 3:4 ratio of 
95:5. No further purification was necessary. Yield: 95\% (4.2 g). Pure regioisomer 3 can be isolated by crystallization in diethyl ether/ $n$-hexane (4:1).

\section{1,2,3,4,6-Penta- $O$-acetyl-D-glucopyranose [6-O-acetyl-1' $\left.-{ }^{13} \mathrm{C}\right](\alpha-2 *)$.}

Acetic anhydride-1,1 $1^{-13} \mathrm{C}_{2}(122 \mu \mathrm{L}, 1.29 \mathrm{mmol})$ was added drop wise to a stirred solution of $1,2,3,4$-tetra- $O$-acetyl- $\alpha$-D-glucopyranose $(300 \mathrm{mg}, 0.86 \mathrm{mmol})$ in anhydrous pyridine $(1 \mathrm{~mL})$ at 0 ${ }^{\circ} \mathrm{C}$. After stirring at room temperature for $16 \mathrm{~h}$, the solvent was evaporated under vacuum, and the residue was purified by flash chromatography (EtOAc/n-hexane 1:2) to afford $335 \mathrm{mg}$ of $\alpha-2 *$ as a white solid (99\% yield). $\underline{R}_{f}$ (EtOAc): 0.64; ${ }^{1} \mathrm{H} \mathrm{NMR}\left(\mathrm{CDCl}_{3}, 600 \mathrm{MHz}\right): \delta 2.00\left(\mathrm{~s}, 3 \mathrm{H}, \mathrm{CH}_{3}\right), 2.02$ $\left(\mathrm{s}, 3 \mathrm{H}, \mathrm{CH}_{3}\right), 2.03\left(\mathrm{~s}, 3 \mathrm{H}, \mathrm{CH}_{3}\right), 2.08\left(\mathrm{~d}, 3 \mathrm{H}, \mathrm{CH}_{3},{ }^{2} \mathrm{~J}_{\mathrm{HC}} 7.0 \mathrm{~Hz}\right), 2.17\left(\mathrm{~s}, 3 \mathrm{H}, \mathrm{CH}_{3}\right), 4.08-4.13(\mathrm{~m}$, $2 \mathrm{H}, \mathrm{H}-5+\mathrm{H}-6), 4.25$ (dt, 1H, H-6, ${ }^{2} J_{\mathrm{HH}} 12.1,{ }^{3} J_{\mathrm{HH}} 4.2 \mathrm{~Hz}$ ), 5.09 (dd, 1H, H-2, ${ }^{3} J_{\mathrm{HH}} 10.3,{ }^{3} J_{\mathrm{HH}} 3.7$ $\mathrm{Hz}), 5.13\left(\mathrm{t}, 1 \mathrm{H}, \mathrm{H}-4,{ }^{3} J_{\mathrm{HH}} 9.8 \mathrm{~Hz}\right), 5.46\left(\mathrm{t}, 1 \mathrm{H}, \mathrm{H}-3,{ }^{3} J_{\mathrm{HH}} 9.8 \mathrm{~Hz}\right), 6.32\left(\mathrm{~d}, 1 \mathrm{H}, \mathrm{H}-1,{ }^{3} J_{\mathrm{HH}} 3.7 \mathrm{~Hz}\right)$; ${ }^{13} \mathrm{C} \mathrm{NMR}\left(\mathrm{CDCl}_{3}, 150.5 \mathrm{MHz}\right): \delta 20.3\left(\mathrm{CH}_{3}\right), 20.4\left(\mathrm{CH}_{3}\right), 20.5\left(\mathrm{CH}_{3}\right), 20.6\left(\mathrm{CH}_{3}\right), 20.7\left(\mathrm{~d}, \mathrm{CH}_{3}\right.$, $\left.{ }^{2} J_{\mathrm{CC}} 59 \mathrm{~Hz}\right), 20.8\left(\mathrm{CH}_{3}\right), 61.3\left(\mathrm{CH}_{2}\right), 67.8(\mathrm{C}-4), 69.1(\mathrm{C}-2), 69.7(\mathrm{C}-3+\mathrm{C}-5), 88.9(\mathrm{C}-1), 168.6$ $(\mathrm{C}=\mathrm{O}), 169.3(\mathrm{C}=\mathrm{O}), 169.6(\mathrm{C}=\mathrm{O}), 170.1(\mathrm{C}=\mathrm{O}), 170.5\left({ }^{13} \mathrm{C}=\mathrm{O}\right) ; \mathrm{MS}\left(\mathrm{ESI}^{+}, \mathrm{m} / \mathrm{z}\right): 414\left[(\mathrm{M}+\mathrm{Na})^{+}\right.$, $100 \%]$.

\section{1,2,3,4-Tetra- $O$-acetyl- $\alpha$-D-glucopyranose and $\quad 1,2,3,6$-Tetra- $O$-acetyl- $\alpha$-D-} glucopyranose (3/4). Hygroscopic white solid. ${ }^{1} \mathrm{H} \mathrm{NMR}\left(\mathrm{CDCl}_{3}, 300 \mathrm{MHz}\right): \delta 2.01\left(\mathrm{~s}, 3 \mathrm{H}, \mathrm{CH}_{3}\right.$ of 3), 2.04 (s, 3H, $\mathrm{CH}_{3}$ of 3 ), 2.07 (s, 3H, $\mathrm{CH}_{3}$ of 3), 2.11 (s, 3H, $\mathrm{CH}_{3}$ of 4), 2.13 (s, 3H, $\mathrm{CH}_{3}$ of 4), $2.17\left(\mathrm{~s}, 3 \mathrm{H}, \mathrm{CH}_{3}\right.$ of 3), 3.58 (dd, $2 \mathrm{H}, \mathrm{H}-6$ of $\mathbf{3},{ }^{2} J_{\mathrm{HH}} 12.7,{ }^{3} J_{\mathrm{HH}} 4.1 \mathrm{~Hz}$, and $\mathrm{H}-4$ of 4), 3.72 (dd, $1 \mathrm{H}$, H-6 of $3,{ }^{2} J_{\mathrm{HH}} 12.7,{ }^{3} J_{\mathrm{HH}} 2.3 \mathrm{~Hz}$ ), $3.92\left(\mathrm{ddd}, 2 \mathrm{H}, \mathrm{H}-5\right.$ of $\mathbf{3},{ }^{3} J_{\mathrm{HH}} 10.2 ;{ }^{3} J_{\mathrm{HH}} 4.1,{ }^{3} J_{\mathrm{HH}} 2.2 \mathrm{~Hz}$, and H-5 of $\mathbf{4}), 4.25\left(\mathrm{dd}, 1 \mathrm{H}, \mathrm{H}-6\right.$ of $\left.\mathbf{4},{ }^{2} J_{\mathrm{HH}} 12.6,{ }^{3} J_{\mathrm{HH}} 2.3 \mathrm{~Hz}\right), 4.51\left(\mathrm{dd}, 1 \mathrm{H}, \mathrm{H}-6\right.$ of $\mathbf{4},{ }^{2} J_{\mathrm{HH}} 12.6,{ }^{3} J_{\mathrm{HH}} 3.7$ $\mathrm{Hz}), 5.07\left(\mathrm{dd}, 2 \mathrm{H}, \mathrm{H}-2\right.$ of $\mathbf{3},{ }^{3} J_{\mathrm{HH}} 10.2,{ }^{3} J_{\mathrm{HH}} 3.7 \mathrm{~Hz}$, and H-2 of $\left.\mathbf{4}\right), 5.10$ (t, 1H, H-4 of $\mathbf{3},{ }^{3} J_{\mathrm{HH}} 9.9$ $\mathrm{Hz}), 5.33\left(\mathrm{t}, 1 \mathrm{H}, \mathrm{H}-3\right.$ of $\left.\mathbf{4},{ }^{3} J_{\mathrm{HH}} 10.1 \mathrm{~Hz}\right), 5.52$ (t, 1H, H-3 of $\left.\mathbf{3},{ }^{3} J_{\mathrm{HH}} 9.9 \mathrm{~Hz}\right), 6.29$ (d, 1H, H-1 of 4, $\left.{ }^{3} J_{\mathrm{HH}} 3.7 \mathrm{~Hz}\right), 6.34$ (d, 1H, H-1 of $\left.\mathbf{3},{ }^{3} J_{\mathrm{HH}} 3.7 \mathrm{~Hz}\right)$.

1,2,3,4-Tetra- $\boldsymbol{O}$-acetyl- $\boldsymbol{\alpha}$-D-glucopyranose (3). ${ }^{[17 \mathrm{a}]}$ White solid. $\underline{R}_{f}$ (EtOAc): 0.25 ; mp 102$105^{\circ} \mathrm{C},[\alpha]_{\mathrm{D}}{ }^{20}+117\left(\mathrm{c} 1.1\right.$ in $\left.\mathrm{CHCl}_{3}\right)$; IR (KBr): v 3501, 2962 and $1752 \mathrm{~cm}^{-1} ;{ }^{1} \mathrm{H}$ NMR $\left(\mathrm{CDCl}_{3}, 300\right.$ $\mathrm{MHz}): \delta 2.00\left(\mathrm{~s}, 3 \mathrm{H}, \mathrm{CH}_{3}\right), 2.02\left(\mathrm{~s}, 3 \mathrm{H}, \mathrm{CH}_{3}\right), 2.06\left(\mathrm{~s}, 3 \mathrm{H}, \mathrm{CH}_{3}\right), 2.16\left(\mathrm{~s}, 3 \mathrm{H}, \mathrm{CH}_{3}\right), 3.57(\mathrm{dd}, 1 \mathrm{H}$, H-6, ${ }^{2} J_{\mathrm{HH}} 12.6,{ }^{3} J_{\mathrm{HH}} 4.3 \mathrm{~Hz}$ ), 3.71 (dd, 1H, H-6, ${ }^{2} J_{\mathrm{HH}} 12.6,{ }^{3} J_{\mathrm{HH}} 2.4 \mathrm{~Hz}$ ), 3.91 (ddd, 1H, H-5, ${ }^{3} J_{\mathrm{HH}}$ $\left.10.3,{ }^{3} J_{\mathrm{HH}} 4.1,{ }^{3} J_{\mathrm{HH}} 2.2 \mathrm{~Hz}\right), 5.06\left(\mathrm{dd}, 1 \mathrm{H}, \mathrm{H}-2,{ }^{3} J_{\mathrm{HH}} 10.3,{ }^{3} J_{\mathrm{HH}} 3.7 \mathrm{~Hz}\right), 5.10\left(\mathrm{t}, 1 \mathrm{H}, \mathrm{H}-4,{ }^{3} J_{\mathrm{HH}} 9.5\right.$ $\mathrm{Hz}), 5.50\left(\mathrm{t}, 1 \mathrm{H}, \mathrm{H}-3,{ }^{3} J_{\mathrm{HH}} 9.9 \mathrm{~Hz}\right), 6.33\left(\mathrm{~d}, 1 \mathrm{H}, \mathrm{H}-1,{ }^{3} J_{\mathrm{HH}} 3.7 \mathrm{~Hz}\right) ;{ }^{13} \mathrm{C} \mathrm{NMR}\left(\mathrm{CDCl}_{3}, 75.5 \mathrm{MHz}\right): \delta$ $20.3\left(\mathrm{CH}_{3}\right), 20.4\left(\mathrm{CH}_{3}\right), 20.5\left(\mathrm{CH}_{3}\right), 20.7\left(\mathrm{CH}_{3}\right), 60.7\left(\mathrm{CH}_{2}\right), 68.1(\mathrm{C}-4), 69.2(\mathrm{C}-2), 69.5(\mathrm{C}-3)$, $\left.72.0(\mathrm{C}-5), 89.0(\mathrm{C}-1), 169.0(\mathrm{C}=\mathrm{O}), 169.6(\mathrm{C}=\mathrm{O}), 170.0(\mathrm{C}=\mathrm{O}), 170.1(\mathrm{C}=\mathrm{O}) ; \mathrm{MS}_{(\mathrm{ESI}}^{+}, \mathrm{m} / z\right): 471$ $\left[(\mathrm{M}+\mathrm{Na})^{+}, 100 \%\right]$. 


\section{1,2,3,4-Tetra- $O$-acetyl-6- $O$-benzoyl- $\alpha$-D-glucopyranose (5).}

Benzoyl chloride $(34 \mu \mathrm{L}, 0.293 \mathrm{mmol})$ was added drop wise to a solution of 3 (102 $\mathrm{mg}, 0.293$ $\mathrm{mmol})$ in anhydrous pyridine $(0.5 \mathrm{~mL})$ at $0{ }^{\circ} \mathrm{C}$. After stirring at room temperature for overnight, the solvent was evaporated under vacuum, and the residue subjected to flash chromatography (EtOAc/n-hexane, 2:1), affording 5 as a white solid $\left(116 \mathrm{mg}, 88 \%\right.$ yield). $\underline{R}_{f}$ (50\% $n$ hexane/EtOAc): 0.43; mp 125-127 ${ }^{\circ} \mathrm{C} ;[\alpha]_{\mathrm{D}}{ }^{20}+99$ (c 1.1 in $\left.\mathrm{CHCl}_{3}\right)$; IR (KBr): v 3063, 2940, 1757 and $1724 \mathrm{~cm}^{-1} ; \underline{{ }^{1} \mathrm{H} \mathrm{NMR}}\left(\mathrm{CDCl}_{3}, 600 \mathrm{MHz}\right): \delta 2.03\left(\mathrm{~s}, 3 \mathrm{H}, \mathrm{CH}_{3}\right), 2.04\left(\mathrm{~s}, 3 \mathrm{H}, \mathrm{CH}_{3}\right), 2.05(\mathrm{~s}, 3 \mathrm{H}$, $\mathrm{CH}_{3}$ ), 2.19 (s, 3H, $\mathrm{CH}_{3}$ ), 4.23-4.28 (m, 1H, H-5), 4.39 (dd, $\left.1 \mathrm{H}, \mathrm{H}-6,{ }^{2} J_{\mathrm{HH}} 12.2,{ }^{3} J_{\mathrm{HH}} 3.9 \mathrm{~Hz}\right), 4.49$ $\left(\mathrm{dd}, 1 \mathrm{H}, \mathrm{H}-6,{ }^{2} J_{\mathrm{HH}} 12.4,{ }^{3} J_{\mathrm{HH}} 2.4 \mathrm{~Hz}\right), 5.12\left(\mathrm{dd}, 1 \mathrm{H}, \mathrm{H}-2,{ }^{3} J_{\mathrm{HH}} 10.1,{ }^{3} J_{\mathrm{HH}} 3.8 \mathrm{~Hz}\right), 5.25(\mathrm{t}, 1 \mathrm{H}, \mathrm{H}-4$, $\left.{ }^{3} J_{\mathrm{HH}} 9.9 \mathrm{~Hz}\right), 5.52\left(\mathrm{t}, 1 \mathrm{H}, \mathrm{H}-3,{ }^{3} J_{\mathrm{HH}} 9.8 \mathrm{~Hz}\right), 6.36\left(\mathrm{~d}, 1 \mathrm{H}, \mathrm{H}-1,{ }^{3} J_{\mathrm{HH}} 3.8 \mathrm{~Hz}\right), 7.44\left(\mathrm{t}, 2 \mathrm{H}, \mathrm{H}-m,{ }^{3} J_{\mathrm{HH}}\right.$ $7.3 \mathrm{~Hz}), 7.56\left(\mathrm{t}, 1 \mathrm{H}, \mathrm{H}-p,{ }^{3} J_{\mathrm{HH}} 7.5 \mathrm{~Hz}\right), 8.04$ (d, 2H, H-o, $\left.{ }^{3} J_{\mathrm{HH}} 7.8 \mathrm{~Hz}\right) ;{ }^{13} \mathrm{C} \mathrm{NMR}\left(\mathrm{CDCl}_{3}, 150.5\right.$ MHz): $\delta 20.4\left(\mathrm{CH}_{3}\right), 20.5\left(\mathrm{CH}_{3}\right), 20.6\left(\mathrm{CH}_{3}\right), 20.8\left(\mathrm{CH}_{3}\right), 61.9\left(\mathrm{CH}_{2}\right), 68.2(\mathrm{C}-4), 69.2(\mathrm{C}-2), 69.8$ (C-3+C-5), 89.0 (C-1), 128.4 (C-m), 129.4 (C-i), 129.7 (C-o), 133.2 (C-p), 166.1 (Ph-C=O), 168.7 $(\mathrm{C}=\mathrm{O}), 169.3(\mathrm{C}=\mathrm{O}), 169.6(\mathrm{C}=\mathrm{O}), 170.2(\mathrm{C}=\mathrm{O}) ; \mathrm{MS}\left(\mathrm{ESI}^{+}, \mathrm{m} / \mathrm{z}\right): 475\left[(\mathrm{M}+\mathrm{Na})^{+}, 100 \%\right]$.

\section{Enzymatic hydrolysis of 5.}

A mixture of 5 (48.3 mg, $0.107 \mathrm{mmol})$, Candida rugosa lipase $(24 \mathrm{mg})$, and $25 \mathrm{mM}$ phosphate buffer $\mathrm{pH} 4$ which contain $20 \%$ of 1,4-dioxane $(6 \mathrm{~mL})$ was stirred $(250 \mathrm{rpm})$ at $30{ }^{\circ} \mathrm{C}$ during $49 \mathrm{~h}$. The suspension was filtered on celite, the enzyme washed with 1,4-dioxane and EtOAc, and the residue extracted with EtOAc. The combined organic layers were washed with aqueous $\mathrm{NaHCO}_{3}$. Solvents were evaporated under vacuum, and the residue analyzed by ${ }^{1} \mathrm{H}$ NMR, which indicated a 3:4 ratio of $97: 3$. Yield: $91 \%(34 \mathrm{mg})$.

\section{1,2,3,4-Tetra- $O$-acetyl-6- $O$-diphenyloxyphosphoryl- $\alpha$-D-glucopyranose (7).}

Diphenyl chlorophosphate $(1.7 \mathrm{~mL}, 8.31 \mathrm{mmol}), \mathrm{Et}_{3} \mathrm{~N}(1.2 \mathrm{~mL}, 8.31 \mathrm{mmol})$, and a catalytic amount of DMAP were added to a solution of $\mathbf{3 / 4}$ [(ratio $\alpha / \beta: 95 / 5), 2.41 \mathrm{~g}, 6.92 \mathrm{mmol})$ in anhydrous $\mathrm{CH}_{2} \mathrm{Cl}_{2}(43 \mathrm{~mL})$. The mixture was stirred at room temperature for $6 \mathrm{~h}$. $\mathrm{MeOH}(3 \mathrm{~mL})$ was added and after 30 min of additional stirring, solvents were evaporated under vacuum. The yellow-orange residue was filtered through a short column of silica gel (EtOAc/n-hexane, 2:3), and the resulting white solid (mixture of 7/8) was dissolved in $\mathrm{CHCl}_{3}$ and precipitated in $n$-hexane to afford $3.5 \mathrm{~g}$ of 7 (85\% yield). 7: $\underline{R}_{f}\left(50 \% n\right.$-hexane/EtOAc): $0.26 ; \mathrm{mp} 97-100{ }^{\circ} \mathrm{C} ;[\alpha]_{\mathrm{D}}{ }^{20}+74\left(\mathrm{c} 1.1\right.$ in $\left.\mathrm{CHCl}_{3}\right) ; \mathrm{IR}$ (KBr): v 3054, 2965, 1738 and $1590 \mathrm{~cm}^{-1} ;{ }^{1} \mathrm{H} \mathrm{NMR}\left(\mathrm{CDCl}_{3}, 400 \mathrm{MHz}\right): \delta 1.99$ (s, 3H, $\left.\mathrm{CH}_{3}\right), 2.01$ (s, 3H, $\mathrm{CH}_{3}$ ), 2.02 (s, 3H, $\mathrm{CH}_{3}$ ), 2.11 (s, 3H, $\mathrm{CH}_{3}$ ), 4.12-4.38 (m, 3H, H-5+2H-6), 4.97 (dd, 1H, H$\left.2,{ }^{3} J_{\mathrm{HH}} 10.2,{ }^{3} J_{\mathrm{HH}} 3.7 \mathrm{~Hz}\right), 5.08\left(\mathrm{t}, 1 \mathrm{H}, \mathrm{H}-4,{ }^{3} J_{\mathrm{HH}} 10.1 \mathrm{~Hz}\right), 5.44\left(\mathrm{t}, 1 \mathrm{H}, \mathrm{H}-3,{ }^{3} J_{\mathrm{HH}} 9.8 \mathrm{~Hz}\right), 6.25(\mathrm{~d}$, $\left.1 \mathrm{H}, \mathrm{H}-1,{ }^{3} J_{\mathrm{HH}} 3.8 \mathrm{~Hz}\right), 7.19-7.34$ (m, $10 \mathrm{H}$ aromatics); ${ }^{13} \mathrm{C} \mathrm{NMR}\left(\mathrm{CDCl}_{3}, 100.6 \mathrm{MHz}\right): \delta 20.3\left(\mathrm{CH}_{3}\right)$, 
$20.4\left(\mathrm{CH}_{3}\right), 20.5\left(\mathrm{CH}_{3}\right), 20.7\left(\mathrm{CH}_{3}\right), 66.4\left(\mathrm{~d}, \mathrm{CH}_{2},{ }^{2} J_{\mathrm{CP}} 5.2 \mathrm{~Hz}\right), 67.8(\mathrm{C}-4), 68.9(\mathrm{C}-2), 69.7(\mathrm{C}-3)$, $70.2\left(\mathrm{~d}, \mathrm{C}-5,{ }^{3} J_{\mathrm{CP}} 6.9 \mathrm{~Hz}\right), 88.7(\mathrm{C}-1), 119.9$ (apparent t, C- $o,{ }^{3} J_{\mathrm{CP}} 4.7 \mathrm{~Hz}$ ), $125.4(\mathrm{C}-p)$; 129.7 (C$m) ; 150.2\left(\mathrm{~d}, \mathrm{C}-i,{ }^{2} J_{\mathrm{CP}} 4.6 \mathrm{~Hz}\right) ; 168.5(\mathrm{C}=\mathrm{O}), 169.2(\mathrm{C}=\mathrm{O}), 169.4(\mathrm{C}=\mathrm{O}), 170.1(\mathrm{C}=\mathrm{O}) ; \underline{{ }^{31} \mathrm{P} \text { NMR }}$ $\left(\mathrm{CDCl}_{3}, 162.0 \mathrm{MHz}\right): \delta$-11.99; HRMS (EI): Calcd for $\mathrm{C}_{26} \mathrm{H}_{29} \mathrm{O}_{13} \mathrm{P}\left(\mathrm{M}^{+}\right)$: 580.13458. found 580.13459. 8: $\underline{R}_{f}\left(50 \% n\right.$-hexane/EtOAc): 0.39; $[\alpha]_{\mathrm{D}}{ }^{20}+40$ (c 1.7 in $\left.\mathrm{CHCl}_{3}\right)$; IR $(\mathrm{NaCl}): v 2960$ and $1756 \mathrm{~cm}^{-1} ; \underline{{ }^{1} \mathrm{H} \mathrm{NMR}}\left(\mathrm{CDCl}_{3}, 400 \mathrm{MHz}\right): \delta 1.87\left(\mathrm{~s}, 3 \mathrm{H}, \mathrm{CH}_{3}\right), 1.96\left(\mathrm{~s}, 6 \mathrm{H}, 2 \mathrm{CH}_{3}\right), 2.14\left(\mathrm{~s}, 3 \mathrm{H}, \mathrm{CH}_{3}\right)$, 4.07-4.14 (m, 2H, H-5+H-6), 4.25 (apparent d, 1H, H-6, ${ }^{2} J_{\mathrm{HH}} 11.4 \mathrm{~Hz}$ ), 4.81 (c, $1 \mathrm{H}, \mathrm{H}-4,{ }^{3} J_{\mathrm{HH}} 9.4$ $\mathrm{Hz}), 5.04\left(\mathrm{dd}, 1 \mathrm{H}, \mathrm{H}-2,{ }^{3} J_{\mathrm{HH}} 10.2,{ }^{3} J_{\mathrm{HH}} 3.8 \mathrm{~Hz}\right), 5.61\left(\mathrm{t}, 1 \mathrm{H}, \mathrm{H}-3,{ }^{3} J_{\mathrm{HH}} 9.8 \mathrm{~Hz}\right), 6.28$ (d, 1H, H-1, $\left.{ }^{3} J_{\mathrm{HH}} 3.6 \mathrm{~Hz}\right), 7.12-7.31(\mathrm{~m}, 10 \mathrm{H}$ aromatics $) ;{ }^{13} \mathrm{C} \mathrm{NMR}\left(\mathrm{CDCl}_{3}, 100.6 \mathrm{MHz}\right): \delta 20.1\left(\mathrm{CH}_{3}\right), 20.3$ $\left(\mathrm{CH}_{3}\right), 20.5\left(\mathrm{CH}_{3}\right), 20.6\left(\mathrm{CH}_{3}\right), 61.2\left(\mathrm{CH}_{2}\right), 69.1(\mathrm{C}-2), 69.4(\mathrm{C}-3), 69.9\left(\mathrm{~d}, \mathrm{C}-5,{ }^{3} J_{\mathrm{CP}} 6.2 \mathrm{~Hz}\right), 73.3$ (d, C-4, ${ }^{2} J_{\mathrm{CP}} 4.3 \mathrm{~Hz}$ ), 88.6 (C-1), 119.6 (apparent t, C- $o,{ }^{3} J_{\mathrm{CP}} 5.5 \mathrm{~Hz}$ ), 125.4 (C-p); $129.6(\mathrm{C}-m)$; $149.9\left(\mathrm{~d}, \mathrm{C}-i,{ }^{2} J_{\mathrm{CP}} 5.3 \mathrm{~Hz}\right) ; 150.0\left(\mathrm{~d}, \mathrm{C}-i,{ }^{2} J_{\mathrm{CP}} 5.6 \mathrm{~Hz}\right) ; 168.3(\mathrm{C}=\mathrm{O}), 169.3(\mathrm{C}=\mathrm{O}), 169.8(\mathrm{C}=\mathrm{O})$, 170. $(\mathrm{C}=\mathrm{O}) ;{ }^{31} \mathrm{P} \mathrm{NMR}\left(\mathrm{CDCl}_{3}, 162.0 \mathrm{MHz}\right): \delta-12.61 ; \mathrm{MS}\left(\mathrm{ESI}^{+}, \mathrm{m} / z\right): 581\left[(\mathrm{M}+\mathrm{H})^{+}, 19 \%\right], 603$ $\left[(\mathrm{M}+\mathrm{Na})^{+}, 100 \%\right]$ and $619\left[(\mathrm{M}+\mathrm{K})^{+}, 55 \%\right]$.

\section{1,2,3,4-Tetra- $O$-acetyl- $\alpha$-D-glucopyranosyl-6-phosphoric acid (9).}

A solution of 7 (2.29 g, $3.95 \mathrm{mmol})$ in anhydrous $\mathrm{MeOH}(23 \mathrm{~mL})$ was added to a flask containing $\mathrm{PtO}_{2}$ (445 mg, $1.96 \mathrm{mmol}$ ) and stirred under a positive pressure of hydrogen (balloon). The suspension was stirred for $16 \mathrm{~h}$ at room temperature. Then, the mixture was filtered on celite and concentrated to give 9 as a white solid in quantitative yield $(1.69 \mathrm{~g})$. The crude was sufficiently pure for the next step. $[\alpha]_{\mathrm{D}}{ }^{20}+91(\mathrm{c} 0.8$ in $\mathrm{MeOH})$; IR $(\mathrm{KBr}):$ v 3423 and $1638 \mathrm{~cm}^{-1} ;{ }^{1} \mathrm{H}$ NMR $(\mathrm{MeOH}-$ $\left.d_{4}, 300 \mathrm{MHz}\right): \delta 2.15\left(\mathrm{~s}, 3 \mathrm{H}, \mathrm{CH}_{3}\right), 2.17\left(\mathrm{~s}, 6 \mathrm{H}, \mathrm{CH}_{3}\right), 2.27\left(\mathrm{~s}, 3 \mathrm{H}, \mathrm{CH}_{3}\right), 2.37\left(\mathrm{~s}, 3 \mathrm{H}, \mathrm{CH}_{3}\right), 4.16-$ 440 (m, 3H, H-5+2H-6), 5.25 (dd, 1H, H-2, $\left.{ }^{3} J_{\mathrm{HH}} 10.2,{ }^{3} J_{\mathrm{HH}} 3.4 \mathrm{~Hz}\right), 5.34\left(\mathrm{t}, 1 \mathrm{H}, \mathrm{H}-4,{ }^{3} J_{\mathrm{HH}} 9.3 \mathrm{~Hz}\right)$, $5.63\left(\mathrm{t}, 1 \mathrm{H}, \mathrm{H}-3,{ }^{3} J_{\mathrm{HH}} 9.8 \mathrm{~Hz}\right), 6.49\left(\mathrm{~d}, 1 \mathrm{H}, \mathrm{H}-1,{ }^{3} J_{\mathrm{HH}} 3.4 \mathrm{~Hz}\right) ;{ }^{13} \mathrm{C} \mathrm{NMR}\left(\mathrm{MeOH}-d_{4}, 75.5 \mathrm{MHz}\right) ; \delta$ $20.3\left(\mathrm{CH}_{3}\right), 20.6\left(2 \mathrm{CH}_{3}\right), 20.7\left(\mathrm{CH}_{3}\right), 65.6\left(\mathrm{CH}_{2}\right), 69.4(\mathrm{C}-4), 70.7(\mathrm{C}-2), 71.3(\mathrm{C}-3), 71.9(\mathrm{C}-5)$, $90.1(\mathrm{C}-1), 170.6(\mathrm{C}=\mathrm{O}), 171.1(\mathrm{C}=\mathrm{O}), 171.3(\mathrm{C}=\mathrm{O}), 171.7(\mathrm{C}=\mathrm{O}) ;{ }^{31} \mathrm{P} \mathrm{NMR}\left(\mathrm{MeOH}-d_{4}, 121.5\right.$

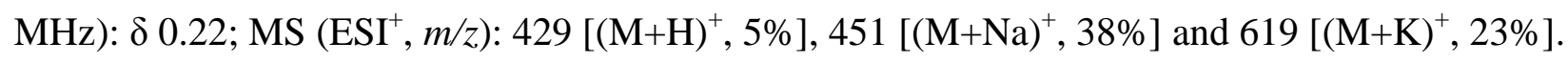

\section{D-Glucose-6-phosphate (10).}

Potassium carbonate $(387 \mathrm{mg}, 2.80 \mathrm{mmol})$ was added to a solution of 9 (1 g, $2.34 \mathrm{mmol})$ in anhydrous $\mathrm{MeOH}(40 \mathrm{~mL})$ at $0{ }^{\circ} \mathrm{C}$. After being stirred for $28 \mathrm{~h}$ at $0{ }^{\circ} \mathrm{C}$ a precipitate was observed, which was isolated by filtration. The white solid was dissolved in water and Dowex 50Wx4-400 $\left(\mathrm{H}^{+}\right.$form) was added. The mixture was stirred for $30 \mathrm{~min}$, the resin was filtered, and the filtrate evaporated to afford $602 \mathrm{mg}$ of $\mathbf{1 0}$ (99\% yield) (ratio $\alpha / \beta \square: 40 / 60)$. $[\alpha]_{\mathrm{D}}{ }^{20}+24$ (c 1.1 in $\mathrm{D}_{2} \mathrm{O}$ ); ${ }^{1} \mathrm{H}$ $\underline{\mathrm{NMR}}\left(\mathrm{D}_{2} \mathrm{O}, 400 \mathrm{MHz}\right): \delta 3.10\left(\mathrm{t}, 1 \mathrm{H}, \mathrm{H}-2 \boldsymbol{\beta}\right.$ anomer, $\left.{ }^{3} J_{\mathrm{HH}} 8.1 \mathrm{~Hz}\right), 3.31-4.11(\mathrm{~m}, 11 \mathrm{H}), 4.53(\mathrm{~d}, 1 \mathrm{H}$, 
H-1 $\beta$ anomer, $\left.{ }^{3} J_{\mathrm{HH}} 7.9 \mathrm{~Hz}\right), 5.10\left(\mathrm{~d}, 1 \mathrm{H}, \mathrm{H}-1 \alpha\right.$ anomer, $\left.{ }^{3} J_{\mathrm{HH}} 3.5 \mathrm{~Hz}\right) ;{ }^{13} \mathrm{C} \mathrm{NMR}\left(\mathrm{D}_{2} \mathrm{O}, 100.6 \mathrm{MHz}\right)$; 66.8 (C-6 $\boldsymbol{\alpha}$ anomer and $\boldsymbol{\beta}$ anomer), 70.2, $72.3\left(\mathrm{~d}, J_{\mathrm{CP}} 8.1 \mathrm{~Hz}\right), 73.6,74.8,76.2,76.6\left(\mathrm{~d}, J_{\mathrm{CP}} 8.1 \mathrm{~Hz}\right)$, 77.7, 94.4 (C-1 $\boldsymbol{\alpha}$ anomer), 98.2 (C-1 $\boldsymbol{\beta}$ anomer); ${ }^{31} \mathrm{P}$ NMR $\left(\mathrm{D}_{2} \mathrm{O}, 162.0 \mathrm{MHz}\right): \delta$ 0.79; MS (ESI', $m / z): 259\left[(\mathrm{M}-\mathrm{H})^{-}, 100 \%\right]$.

\section{Supporting Information Available}

General spectroscopic and experimental data, and molecular modeling calculations description are shown. Furthermore, copies of ${ }^{1} \mathrm{H},{ }^{13} \mathrm{C}$, DEPT, and ${ }^{31} \mathrm{P}$ NMR spectra in addition of some 2D NMR experiments are included.

\section{Acknowledgments}

The authors are grateful to Dr. P. Herrero for the support in the enzymatic assays of G-6-P. Financial support of this work by the Sixth Framework Program of the European Community (EU04-LSHB-2003-503017) is gratefully acknowledged. S. F. thanks MEC for a personal grant (Ramón y Cajal Program).

\section{References}

[1] Fr Pat. 5782 19680318, 1968; CAN 71:3626. Hypertensive glucose 6-(sodium hydrogen phosphate).

[2] D. Champmartin, P. Rubini, A. Lakatos and T. Kiss, J. Inorg. Biochem. 2001, 84, 13-21.

[3] a) T. Aoki, K. Kitahata, T. Fukumoto, Y. Sugimoto, H. R. Ibrahim, T. Kimura, Y. Kato and T. Matsuda, Food Res. Int. 1997, 30, 401-406; b) Y. Kato, T. Aoki, N. Kato, N. Nakamura and T. Matsuda, J. Agric. Food Chem. 1995, 43, 301-305; c) G. Matheis, Food Chem. 1991, 39, 13-26.

[4] a) T. Eguchi, S. Sasaki, Z. Huang and K. Kakinuma, J. Org. Chem. 2002, 67, 3979-3984; b) N. Yamauchi and K. Kakinuma, J. Org. Chem. 1995, 60, 5614-5619; c) Aminocyclitol antibiotics, ed. K. L. Rinehart Jr. and T.Suami, ACS Symposium Series No.125; American Chemical Society, Washington, DC, 1980; d) K. L. Rinehart, Jr. and R. M. Stroshane, J. Antibiotic. 1976, 29, 319-353. [5] F. Foufelle, B. Gouhot, J. P. Pegorier, D. Perdereau, J. Girard and P. Ferre, J. Biol. Chem. 1992, 267, 20543-20546.

[6] R. Robison and E. J. King, Biochem. J. 1931, 25, 323-328.

[7] a) D. C. Crans and G. M. Whitesides, J. Org. Chem. 1983, 48, 3130-3132; b) A. Pollak, R. L. Baughn and G. M. Whitesides, J. Am. Chem. Soc. 1977, 99, 2366-2367.

[8] B. P. Colowick and E. W. Sutherland, J. Biol. Chem. 1942, 44, 423-437.

[9] C. Neuberg, H. Lustig, M. A. Rathenberg, Arch. Biochem. 1943, 3, 33-44. 
[10] T. van Herk, A. F. Hartog, A. M. van der Burg and R. Wever, Adv. Synth. Catal. 2005, 347, 1155-1162.

[11] a) H. A. Lardy and H. O. L. Fischer, Biochem. Prep. 1952, 2, 39-44; b) H. A. Lardy and H. O. L. Fischer, J. Biol. Chem. 1946, 164, 513-519.

[12] R. L. Whistler, L. W. Doner and K. Martin, Methods Carbohydr. Chem. 1972, 6, 411-412.

[13] a) R. Hua, S. Zhang and Y. Song, Huaxue Tongbao 1992, 33-34; b) K. Schutzner, Cesk. Farm. 1974, 23, 34-36; Chem. Abstr. 1974, 81, 13715j; c) P. A. Levene and A. L. Raymond, J. Biol. Chem. 1931, 92, 757-763.

[14] a) F. R. Zuleski and E. T. McGuinness, J. Labelled Compd. 1969, 5, 371-376; b) M. Viscontini and C. Oliver, Helv. Chim. Acta 1953, 36, 466-470; c) J. E. Seegmiller and B. L. Horecker, J. Biol. Chem. 1951, 192, 175-180.

[15] a) C.-H. Wong and G. M. Whitesides, J. Am. Chem. Soc. 1981, 103, 4890-4899; b) C.-H. Wong, J. Gordon, C. L. Cooney and G. M. Whitesides, J. Org. Chem. 1981, 46, 4676-4679.

[16] a) F. Ganske and U. T. Bornscheuer, Org. Lett. 2005, 7, 3097-3098; b) T.-C. Chien and J.-W. Chern, Carbohydr. Res. 2004, 339, 1215-1217; c) M.-J. Kim, M. Y. Choi, J. K. Lee and Y. Ahn, J. Mol. Catal. B: Enzym. 2003, 26, 115-118; d) S. Park and R. J. Kazlauskas, J. Org. Chem. 2001, 66, 8395-8401; e) R. Khan, L. Groppen, P. A. Konpwicz, M. Matulová and S. Paoletti, Tetrahedron Lett. 1993, 34, 7767-7770; f) D. G. Drueckhamer, J. W. Hennen, R. L. Pederson, C. F. Barbas, C. M. Gautheron, T. Krach and C.-H. Wong, Synthesis 1991, 7, 499-525.

[17] a) G. Fernández-Lorente, J. M. Palomo, J. Cocca, C. Mateo, P. Moro, M. Terreni, R. Fernández-Lafuente and J. M. Guisán, Tetrahedron 2003, 59, 5705-5711; b) M. Terreni, R. Salvetti, L. Linati, R. Fernández-Lafuente, G. Fernández-Lorente, A. Bastida and J. M. Guisán, Carbohydr. Res. 2002, 337, 1615-1621; c) A. Bastida, R. Fernández-Lafuente, G. Fernández-Lorente and J. M. Guisán, Bioorg. Med. Chem. Lett. 1999, 9, 633-636.

[18] T. Horrobin, C. H. Tran and D. Crout, J. Chem. Soc., Perkin Trans. 1 1998, 1069-1080.

[19] P. F. Schatz, J. Chem. Edu. 2001, 78, 1378.

[20] $\alpha$-D-1,2,3,4,6-pentaacetylglucose purchased from Innovassynth Technologies (www.Innovassynth.com) had $6 \%$ of $\beta$-D-1,2,3,4,6-pentaacetylglucose.

[21] P. M. Collins and R. J. Ferrier, in Monosaccharides. Their Chemistry and Their Roles in Natural Products, John Wiley \& Sons, New York, 1995, pp 360.

[22] A. Procopio, R. Dalpozzo, A. De Nino, L. Maiuolo, B. Russo and G. Sindona, Adv. Synth. Catal. 2004, 346, 1465-1470.

[23] a) G. Bartoli, R. Dalpozzo, A. De Nino, L. Maiuolo, M. Nardi, A. Procopio and A. Tagarelli, Green Chem. 2004, 6, 191-192; b) R. Dalpozzo, A. De Nino, L. Maiuolo, A. Procopio, M. Nardi, G. Bartoli and R. Romeo, Tetrahedron Lett. 2003, 44, 5621-5624. 
[24] a) A. K. Misra, P. Tiwari and S. K. Madhusudan, Carbohydr. Res. 2005, 340, 325-329; b) A.

K. Chakraborti and R. Gulhane, Chem. Commun. 2003, 1896-1897.

[25] K. P. R. Kartha and R. A. Field, Tetrahedron 1997, 53, 11753-11766.

[26] A. Orita, Y. Hamada, T. Nakano, S. Toyoshima and J. Otera, Chem. Eur. J. 2001, 7, 33213327.

[27] Y. S. Sanghvi, Z. Guo, H. N. Pfundheller and A. Converso, Org. Proc. Res. Dev. 2000, 4, 175181.

[28] E. Postma, C. Verduyn, W. A. Scheffers and J. P. van Dijken, Appl. Environ. Microbiol. 1989, 55, 468-477.

[29] Spectrometric assays were carried out at $340 \mathrm{~nm}$ and $25{ }^{\circ} \mathrm{C}$. The reaction rates were proportional to the amount of G-6-P added. The assay mixture contained Tris hydrochloride buffer $(\mathrm{pH} 8,50 \mathrm{mM}), \mathrm{MgCl}_{2}(5 \mathrm{mM})$, and $\mathrm{NADP}^{+}(0.4 \mathrm{mM})$. The reaction was started with $5 \mathrm{mM}$ glucose 6-phosphate.

[30] P. Grochulski, P. Bouthillier, R. J. Kazlauskas, A. N. Serreqi, J. D. Schrag, E. Ziomek and M. Cygler, Biochemistry 1994, 33, 3494-3500.

[31] Other examples of molecular modeling or structural studies on CRL: a) J. Schmitt, S. Brocca, R. D. Schmid and J. Pleiss, Protein Eng. 2002, 15, 595-601; b) T. Schulz, R. D. Schmid and J. Pleiss, J. Mol. Model. 2001, 7, 265-270; c) M. Cygler and J. D. Schrag, Biochim. Biophys. Acta 1999, 1441, 205-214; d) M. Botta, E. Cernia, F. Corelli, F. Manetti and S. Soro, Biochim. Biophys. Acta 1997, 1337, 302-310; e) M. Holmquist, F. Hæffner, T. Norin and K. Hult, Protein Sci. 1996, 5, 83-88.

[32] To identify hydrogen bonds, a donor-acceptor separation of less than $3.20 \AA$ and a donorhydrogen-acceptor angle of $120^{\circ}$ or greater are required.

[33] It has been previously described another example where this amino acid seemed to have a remarkable effect in the hydrolysis of 1-pyridylethanol esters. See, for instance: F. Bellezza, A. Cipiciani, G. Cruciani and F. Fringuelli, J. Chem. Soc., Perkin Trans. 1 2000, 4439-4444.

[34] For other examples of influenced selectivity in enzymes by remote interactions, see: a) I. Lavandera, S. Fernández, J. Magdalena, M. Ferrero, H. Grewal, C. K. Savile, R. J. Kazlauskas and V. Gotor, ChemBioChem 2006, 7, 693-698; b) B. Botta, G. Zappia, A. Tafi, M. Botta, F. Manetti, E. Cernia, G. Milana, C. Palocci, S. Soro and G. D. Monache, J. Mol. Catal. B: Enzymatic 2002, 16, 241-247; c) D. G. Gascoyne, H. L. Finkbeiner, K. P. Chan, J. L. Gordon, K. R. Stewart and R. J. Kazlauskas J. Org. Chem. 2001, 66, 3041-3048.

[35] a) W. D. Cornell, P. Cieplak, C. I. Bayly and P. A. Kollman, J. Am. Chem. Soc. 1993, 115, 9620-9631; b) S. J. Weiner, P. A. Kollman, D. A. Case, U. C. Singh, C. Ghio, G. Alagona, S. Profeta, P. Weiner, J. Am. Chem. Soc. 1984, 106, 765-784. 
[36] I. Lavandera, S. Fernández, J. Magdalena, M. Ferrero, R. J. Kazlauskas and V. Gotor, ChemBioChem 2005, 6, 1381-1390.

[37] DeLano, W. L. "The PyMOL Molecular Graphics System”; DeLano Scientific LLC, San Carlos, CA, USA; http://www.pymol.org

\section{Table of Contents}

Chemoenzymatic Synthesis of G-6-P

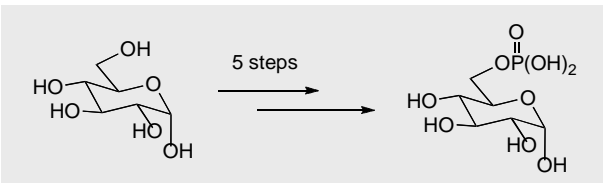

Glucose-6-phosphate

A concise chemoenzymatic synthesis of glucose-6-phosphate is described. Candida rugosa lipase was found to be an efficient catalyst for both regioand stereoselective deacetylation of the primary hydroxyl group in the peracetylated D-glucose. The high overall yield and the easy scalability makes this chemoenzymatic strategy attractive for industrial application. Furthermore, molecular modeling of phosphonate transition-state analogue for the enzymatic step supports the substrate selectivity observed.
Tatiana Rodríguez-Pérez, Iván Lavandera, Susana Fernández, Yogesh

S. Sanghvi, Miguel Ferrero, $*$ and Vicente Gotor*

Page No. - Page No.

Novel and Efficient Chemoenzymatic Synthesis of D-Glucose-6-Phosphate and Molecular Modeling Studies on the Selective Biocatalysis

Keywords: Carbohydrates, Enzyme Catalysis, Molecular Modeling 